\title{
KAZNENO DJELO UTAJE POREZA KAO OBLIK POREZNE EVAZIJE S POSEBNIM OSVRTOM NA POSLOVANJE PREKO POREZNIH UTOČIŠTA
}

U radu se raspravlja o tome je li svako neplaćanje poreza porezna utaja, tj. utaja poreza, te je li svaka utaja poreza kazneno djelo. S tim u vezi željelo se dodatno istražitije li poslovanje preko tzv. poreznih oaza, zakonita ili nezakonita aktivnost, odnosno porezna evazija, tj. može li se u tim slučajevima uopće govoriti o poreznoj evaziji. Postavlja se i dodatno pitanje, ako se utvrdi da poslovanje preko poreznih oaza, tj. utočišta, jest porezna evazija, je li u tim slučajevima riječ o kaznenom djelu utaje poreza. U tom su kontekstu postavljene dvije hipoteze. H1: svaka porezna evazija veća od 20.000,00 kuna kazneno je djelo utaje poreza. H2: poslovanje preko poreznih utočišta nezakonito je i označuje kazneno djelo utaje poreza.

Ključne riječi: porezi, porezna evazija, utaja poreza, kazneno djelo utaje poreza, porezne oaze

\section{UVOD}

Svaka država regulira plaćanje poreza koji su krucijalni za njezino normalno funkcioniranje. Ta obveza nije nešto novo, tvorevina novih vladajućih struktura i modernog doba, nego je bila prisutna u povijesti u gotovo svim društvenim uređenjima, a najraniji zapisi sežu u 2000. god. pr. Kr., u vrijeme Babilona.' Porezi su glavni „fiskal-

Dominik Clavina, mag. iur., odvjetnički vježbenik u odvjetničkom društvu Čačić \& Partneri (Law Trainee, Law office Čačić \& Partners): dominik170417@gmail.com

ORCID ID: orcid.org/0000-0001-5806-7433.

** Dr. sc. Marta Dragičević Prtenjača, docentica na Katedri za kazneno pravo Pravnog fakulteta Sveučilišta u Zagrebu, (Assistant Professor at Chair of Criminal Law, Faculty of Law, University of Zagreb): mdragicev@gmail.com

ORCID ID: orcid.org/0000-0001-9666-4765.

Rad se temelji na diplomskom radu Dominika Clavine Kazneno djelo utaje poreza i odnos s ugovorima 0 dvostrukom oporezivanju koji je bio napisan pod mentorstvom dr. sc. Marte Dragičević Prtenjače, docentice na Katedri za kazneno pravo Pravnog fakulteta u Zagrebu.

1 O obvezi plaćanja poreza u to vrijeme vidi Kurtović, 2005, 50. 
ni instrument prikupljanja javnih prihoda u cilju podmirivanja javnih rashoda“z osiguravanje (financijskog) funkcioniranja svake države. Prema tome, u interesu je svake države da se porezi redovito plaćaju, i ta je obveza regulirana zakonima.

Međutim, iako postoji zakonska obveza plaćanja poreza, katkad može doći i do neplaćanja poreza. Pitanje je samo je li neplaćanje poreza uvijek nelegalno ili katkad može biti riječ i o legalnome neplaćanju poreza. Tako Sertić razlikuje izbjegavanje plaćanja poreza (tax avoidance) koje bi bilo legalna radnja i poreznu evaziju (tax evasion) koja je nedopuštena, tj. nezakonita. ${ }^{3}$ Sertić smatra sve porezne evazije nezakonitima, a takvo je stajalište, primjerice, zauzeto i u Ujedinjenom Kraljevstvu. ${ }^{4} \mathrm{~S}$ druge strane, samo izbjegavanje plaćanja poreza neće se smatrati nezakonitim postupanjem $^{5}$ ako porezni obveznik ${ }^{6}$ iskorištava tzv. rupe u zakonu poštujući porezne propise, pa time dolazi do tzv. zakonitog izbjegavanja plaćanja poreza (tax avoidance). ${ }^{\mathrm{U}}$ situaciji kada porezni obveznik želi izbjeći plaćanje poreza te dolazi u sukob s poreznim propisima, riječ je o poreznoj evaziji koja može biti prekršaj ili kazneno djelo. Potrebno je još napomenuti da se i neredovito plaćanje poreza smatra poreznom evazijom te će prema svojim karakteristikama biti prekršaj ili kazneno djelo. Također se želi promotriti je li svako poslovanje preko poslovnih subjekata ili s poslovnim subjektima koji se nalaze u tzv. poreznim oazama, odnosno utočištima, samo po sebi zabranjeno i nezakonito, to jest je li takvo postupanje neko kazneno djelo, preciznije, kazneno djelo utaje poreza.

$\mathrm{S}$ tim se u vezi u radu postavljaju dvije hipoteze. H1: svaka porezna evazija veća od 20.000,00 kuna kazneno je djelo utaje poreza. $\mathrm{H} 2$ : poslovanje preko poreznih utočišta nezakonito je i označuje kazneno djelo utaje poreza. Posebno je zanimljivo promotriti, a vezano za prvu postavljenu hipotezu, smatra li se svaka porezna evazija iznosa većega od 20.000,00 kn kaznenim djelom utaje poreza iz članka 256. Kaznenog zakona (dalje u tekstu: KZ) ili u pojedinim slučajevima može biti riječ i o prekršaju. ${ }^{8}$ Provjera navedenih hipoteza provest će se primjenom normativno-deskriptivne, komparativne, statističke te kvalitativne metode (analizom presuda).

2 Cindori; Pilipović; Kalčić, 2015, 25.

3 Sertić, 2012, 40-41.

4 Za više vidi ACCA, Paper F6, Taxation (UK) FA 2013, str. 9, dostupno na https://books.google. $\mathrm{hr} /$ books?id=LSAvDwAAQBA]\&pg=PA9\&lpg=PA9\&dq=tax+evasion+texts\&source=bl\&ot$s=z x Z o w W V f Z o \& s i g=H F C o F Q A z M O i Q g t 72 W n P-Z 1 j u d O w \& h l=h r \& s a=X \& v e d=0 a h U K E w i 9886 \mathrm{mnf}-$ fWAhXJb1AKHTHWCHcQ6AEIQDAF\#v=onepage\&q=tax\%20evasion\%2otexts\&f=false (17.10.2017.).

Drukčije od navedenog u smislu da postoje zakonite i nezakonite porezne evazije vidi Križanec, 2016, dostupno na http://ipf.rs/porezna-evazija/ (13.10.2017.).

5 Sertić, 2012, 40-41.

6 Tko je porezni obveznik, određuje se zakonom kojim se regulira plaćanje pojedine vrste poreza.

7 Za više vidi ACCA (2013), op. cit. (bilj. 4), 9.

Takvu situaciju Križanec naziva legalnom poreznom evazijom. Križanec, 2016.

8 Kazneni zakon, NN, br. 125/11, 144/12, 56/15, 61/15, 101/17. 
Pojam porezne utaje, tj. utaje poreza ${ }^{9}$, puno je širi od pojma kaznenog djela utaje poreza. To je stoga što utaja poreza može biti prekršaj ili kazneno djelo, ovisno o okolnostima pojedinog slučaja. Da bi bila riječ o kaznenom djelu, moraju biti ispunjena sva obilježja iz navedenog članka 256. KZ-a i iznos tako utajenog poreza (ili carine) mora biti viši od $20.000,00 \mathrm{kn}$. S tim u vezi postoje razne definicije utaje poreza. Matković definira utaju poreza kao „nezakonito izbjegavanje porezne obveze koje obuhvaća nezakonite radnje ili propuštanja kojima se porezna obveza prikriva ili izbjegava radi neplaćanja poreza ili plaćanja manjeg poreza nego što zakon propisuje“. ${ }^{\circ}$ Mladineo navodi da je to "namjerno, planirano i smišljeno neprijavljivanje prihoda"." Harel uspoređuje poreznu evaziju s lutrijom; obveznik sam odlučuje hoće li platiti porez u cijelosti ili manji iznos poreza ili uopće neće platiti porez i riskirati da bude uhvaćen i kažnjen te da tada plati kaznu i porez koji nije platio. ${ }^{2}$ Uz uvažavanje svih navedenih definicija utaje poreza, kada se govori o utaji poreza kao kaznenom djelu i posebnom obliku "nezakonite“ porezne evazije, isključivo je relevantna norma sadržana u članku 256. KZ-a.

\section{KAZNENO DJELO UTAJE POREZA ILI CARINE}

Kazneno djelo utaje poreza, punog naziva utaja poreza ili carine, regulirano je, kao što je prije navedeno, člankom 256. KZ-a i nalazi se u Glavi XXIV. (kaznena djela protiv gospodarstva) i u tom se kontekstu smatra gospodarskim kaznenim djelom. Zaštićeno pravno dobro je gospodarstvo ${ }^{13}$, pa se njime želi spriječiti negativan utjecaj na gospodarstvo, ali i stjecanje i zadržavanje protupravno stečene imovinske koristi. Ni navedena inkriminacija ni Kazneni zakon u članku 87. (u kojem su definirani pojmovi i relevantna kaznenopravna terminologija) ne definiraju što su to porezi odnosno carine, nego se indirektno upućuje na primjenu poreznih zakona kojima su definirani pojmovi poreza i carina. S tim u vezi treba primijetiti da, iako su riječi „porez“ i „carine“ normativna obilježja djela, može se reći da je to djelo na neki način slučaj prikrivene blanketne norme (moglo bi se tu normu nazvati blanketna norma u širem smislu jer se blanketna dispozicija shvaća iz sadržaja i smisla norme). ${ }^{14}$ To je stoga što se tek konzultiranjem s poreznim zakonodavstvom i određivanjem navedenih

\footnotetext{
9 O utaji poreza u sportu vidi Sokanović; Šinković; Pajčić, 2012, 803-830.

10 Matković, 2013, 162.

11 Mladineo, 2008, 47.

12 Harel, 2014, 313.

dostupno na: https://books.google.hr/books?id=y89LBAAAQBA]\&pg=PA313\&/pg=PA313\&dq=tax+evasion+texts\&source=bl\&ots=V-iF8CStFs\&sig=k7q2udtmswKIU1Y2eLHtrZUrtNQ\&hl=hr\&sa=X\&ved=0ahUKEwi9886mnffWAhX]b1AKHTHWCHcQ6AEIRTAC\#v=onepage\&q=tax\%20evasion\%2otext$\mathrm{s} \& \mathrm{f}=\mathrm{false}(17.10 .2017$.$) .$

13 Više o gospodarskim kaznenim djelima vidi Novoselec; Roksandić Vidlička, 2010, 699-728.

14 Za više o blanketnoj normi vidi Horvatić; Derenčinović; Cvitanović, 2016, 133-134 i Novoselec, 2016, 46.
} 
pojmova ponajprije poreznim pravom, može shvatiti doseg kaznenopravne norme kaznenog djela utaje poreza ili carine. U tom kontekstu, a s obzirom na važnost pojmova koji se upotrebljavaju pri definiranju i određivanju toga kaznenog djela te na povezanost navedenoga kaznenog djela s poreznim zakonodavstvom, potrebno je na samom početku ovoga rada definirati pojmove poreza i carine. Činjenica je da ne postoji univerzalna definicija koja bi bila prihvaćena u svim državama, pa su tako autori tijekom povijesti davali svoje definicije poreza. ${ }^{15}$ Jelčić, primjerice, definira poreze „kao osnovni financijski instrument prikupljanja prihoda kojima suvremene države podmiruju rashode iz svoje nadležnosti ${ }^{16}{ }^{16} Z$ a potrebe ovog teksta upotrebljavat će se definicija Općega poreznog zakona (dalje u tekstu: OPZ) ${ }^{17}$ koji je u svom članku 2. definirao poreze i carine općenito jer postoje posebne vrste poreza i carina koji su regulirani posebnim zakonodavstvom. „Porezi su novčana davanja i prihod su proračuna koji se koristi za podmirivanje proračunom utvrđenih javnih izdataka. Porezi se ne smatraju povremenim davanjima ${ }^{\text {"18 }}$, a "carina je novčano davanje koje se plaća pri uvozu i izvozu“.19 Svaka država u svojemu poreznom sustavu ima nekoliko desetaka poreza koji se klasificiraju po različitim kriterijima. ${ }^{20}$ Aktualni porezni sustav u Republici Hrvatskoj pokazuje nam kako su porezi podijeljeni u određene skupine i to po razinama u čije proračune ulazi prihod od poreza. ${ }^{21}$ Tako postoje državni porezi (porez na dobit, porez na dodanu vrijednost, posebni porezi i trošarine); županijski porezi (porez na nasljedstva i darove, porez na plovila, porez na cestovna motorna vozila, porez na automate za zabavne igre); gradski ili općinski porezi (prirez porezu na dohodak, porez na potrošnju, porez na kuće za odmor, porez na promet nekretnina, porez na korištenje javnih površina); zajednički porezi (porez na dohodak); porezi na dobitke od igara na sreću i naknade za privređivanje igara na sreću (igre u kasinima i igre klađenja, igre na sreću automatima, naknada za privređivanje prigodnih jednokratnih igara na sreću) i naknada za privređivanje nagradnih igara (propisana

\footnotetext{
${ }_{15}$ „Porezi su naknada za zaštitu koju država pruža svojim građanima. (Samuel v. Pufendorf)“, „Porez je cijena koju građanin plaća državi da bi nadoknadio svoj udio u izdatcima za javne usluge koje će trošiti. (De Vitti de Marco)“, „Porezi su naknade za zajedničke službe. (Joseph v. Sonnenfels)“ itd. Jelčić; Lončarić-Horvat; Šimović; Arbutina; Mijatović, 2008, 81-82.

16 Ibid., 79.

17 Opći porezni zakon, NN, br. 115/16.

18 Čl. 2., st. 2. OPZ-a.

19 Čl. 2., st. 4. OPZ-a.

${ }_{20}$ Najpoznatija je podjela na: 1. neposredne i posredne, 2. subjektne i objektne, 3. sintetičke i analitičke, 4. opće i namjenske, 5. katastarske i tarifne, 6. pretpostavljene i faktične, 7. po vrijednosti i specifične, 8. fundirane i nefundirane, 9. redovne i izvanredne, 10. reparticijske i kvotne, 11. osnovne i dopunske, 12. središnjih i lokalnih tijela. Jelčići idr., 2008, 103-117.

${ }_{21}$ Posebnost je kod zajedničkih poreza činjenica da prihod od poreza na dohodak i poreza na promet nekretnina ulazi dijelom u državni proračun, a dijelom u proračune županije i gradova/općina ili gradova/općina. Jančiev; Supić, 2016, 4, dostupno na https://www.porezna-uprava.hr/HR_publikacije/ Prirucnici_brosure/PorezniSustav_2012.pdf (17.10.2017.).
} 
uplata priređivača nagradnih igara u korist Hrvatskoga crvenog križa). ${ }^{22}$ Predmetnim su zakonom definirana i druga javna davanja čija je bitna karakteristika da je njihova naplata u nadležnosti poreznog tijela. ${ }^{23}$ Međutim, druga javna davanja ne smatraju se izrijekom porezima, i time nisu načelno obuhvaćena navedenom inkriminacijom iz članka 256. KZ-a. Doduše, prema podjeli koju navodi Porezna uprava, trošarine koje se prema OPZ-u smatraju javnim davanjima izrijekom su navedene kao oblik državnog poreza, pa bi time trebale biti obuhvaćene kaznenim djelom utaje poreza ili carine. Iz pregleda sudske prakse uvidjelo se da su slučajevi utaje poreza puno češći od utaje carine (no pretpostavlja se da kod utaje carine postoji velika tamna brojka ponajprije kod otkrivanja i prijavljivanja djela), pa će se u skladu s tim u daljnjem tekstu staviti naglasak na utaju poreza.

\subsection{Biće djela i njegovi modaliteti}

Kazneno djelo utaje poreza ili carine čini neka osoba koja daje netočne ili nepotpune podatke o dohodcima, predmetima ili drugim činjenicama koje su od utjecaja na utvrđivanje iznosa porezne ili carinske obveze s ciljem da ta ili druga osoba potpuno ili djelomično izbjegne plaćanje poreza ili carine, „ili tko s istim ciljem u slučaju obvezne prijave ne prijavi prihod, predmet ili druge činjenice koje su od utjecaja na utvrđivanje porezne ili carinske obveze, pa zbog toga dođe do smanjenja ili neutvrđivanja porezne ili carinske obveze u iznosu koji prelazi dvadeset tisuća kuna", za što se može kazniti kaznom zatvora od šest mjeseci do pet godina. ${ }^{24}$ Iz navedenog se primjećuju dva modaliteta počinjenja temeljnog oblika djela - činjenjem i nečinjenjem.

Prvi modalitet koji je činjenje davanje je lažnih (nepotpunih ili netočnih) podataka o zakonito stečenim dohodcima i predmetima ili o drugim činjenicama koje utječu na utvrđivanje svote porezne obveze. Takvo davanje lažnih podataka podrazumijeva djelomičnu utaju poreza ${ }^{25}$, odnosno djelomičnu defraudaciju poreza. ${ }^{26} \mathrm{U}$ presudi KO-2259/2011 Općinski kazneni sud u Zagrebu presudio je da je „okrivljeni kriv što je od 1. travnja 2006. do 29. veljače 2008. u Zagrebu kao privatni ugostitelj i vlasnik ugostiteljskog obrta u nakani da umanji poreznu obvezu poreza na dodanu vrijed-

\footnotetext{
22 Informacije Porezne uprave dostupne na https://www.porezna-uprava.hr/HR_porezni_sustav/ Stranice/naslovna_tablica_psrh.aspx (16.10.2017.).

Međutim, postoje i drukčije podjele poreza na neposredne i posredne, subjektne i objektne i dr. Za više vidi Cindori; Pilipović; Kalčić, 2015, 27, bilj. 20.

${ }^{23}$ „Drugim javnim davanjima smatraju se trošarine, carine, pristojbe, doprinosi, naknade za koncesije, novčane kazne za porezne prekršaje i sva davanja čije je utvrđivanje i/ili naplata i/ili nadzor prema posebnim propisima u nadležnosti poreznog tijela“. Čl. 2. st. 3. OPZ-a.

24 Čl. 256., st. 1. KZ-a.

${ }^{25}$ Mršić, 2008, 51.

${ }_{26}$ Jelčići drr., 2008, 218.
} 
nost, poreza na potrošnju, poreza na dohodak i prireza poreza na dohodak, u poreznim prijavama koje je predavao nadležnim ispostavama porezne uprave neistinito iskazao promet i ostvareni dohodak... te neistiniti promet nije prijavio kao primitak u podnošenju prijave poreza na dohodak, po kojim prijavama mu je utvrđen manji razrez poreza od pripadajućeg... dakle, s ciljem da on izbjegne djelomično plaćanje poreza dao lažne podatke o zakonito stečenim dohodcima...".

Drugi je modalitet počinjenja nečinjenjem, tj. neprijavljivanje zakonito stečenog prihoda odnosno predmeta ili drugih činjenica koje utječu na utvrđivanje porezne obveze, tzv. potpuna utaja poreza ${ }^{27}$ odnosno potpuna defraudacija poreza. ${ }^{28} \mathrm{U}$ presudi KO-1293/14 Općinski kazneni sud u Zagrebu presudio je da je „okrivljenik kriv što je tijekom 2011. godine u Zagrebu, kao direktor i ovlaštena osoba za potpisivanje dokumentacije platnog naloga... u nakani da uskratom proračunskih sredstva pribavi nepripadnu imovinsku korist društvu s ograničenom odgovornošću... nije nadležnoj poreznoj upravi podnosio mjesečne porezne prijave u kojima je prikazan ostvareni promet čime je društvo s ograničenom odgovornošću izbjeglo plaćanje poreza na dodanu vrijednost u ukupnu iznosu od 46.569,67 kn... dakle, s ciljem da on i druga osoba potpuno izbjegnu plaćanje poreza u slučaju obvezne prijave nije prijavio prihod idruge činjenice koje su od utjecaja na utvrđivanje porezne obveze, pa je zbog toga došlo do neutvrđivanja porezne obveze u iznosu koji prelazi dvadeset tisuća kuna...".

U drugom sličnom predmetu Općinski kazneni sud u Zagrebu, br. KO-93/15, presudio je da je „... okrivljeni kriv što je... dakle, s ciljem da druga osoba djelomično izbjegne plaćanje poreza...." Isto tako počinitelj može biti i odgovorna fizička osoba koja vodi poslove neke pravne osobe, a ona je obvezna podnijeti poreznu prijavu pa je sud presudio da ,... je optuženi kriv što je... u svojstvu direktora društva s ograničenom odgovornošću sa sjedištem u Zagrebu u nakani da istom društvu pribavi nepripadnu materijalnu dobit u znatnom iznosu na štetu proračuna... nije prijavio činjenice koje su od utjecaja na utvrđivanje porezne obveze..." (presuda Općinskoga kaznenog suda u Zagrebu, K-643/2015).

Iz potonjeg je vidljivo da je drugi modalitet počinjenja kaznenog djela utaje poreza i carina nečinjenje iz čega proizlazi da je to i nepravo zakonski regulirano kazneno djelo nečinjenjem čiji zakonski opis kaznenog djela glasi na činjenje i nečinjenje ${ }^{29}$ pa je moguće i blaže kažnjavanje u situaciji kada se to kazneno djelo čini nečinjenjem..$^{30} \mathrm{U}$ tom slučaju počinitelj je osoba koja nije prijavila prihod, predmet ili druge

\footnotetext{
27 Mršić, 2008, 51.

28 Jelčićidr., 2008, 218.

29 Horvatić; Derenčinović; Cvitanović, 2017, 14.

${ }_{30}$ Čl. 20., st. 3. KZ-a

Kako su kaznena djela nečinjenja posebna kategorija kaznenih djela, to bi djelo prema prijašnjoj podjeli, kod koje je glavno razlikovanje pravih od nepravih kaznenih djela nečinjenjem bilo u tome
} 
činjenice relevantne za utvrđivanje porezne (ili carinske) obveze kada je to bila obvezna učiniti. U tom se kontekstu može zaključiti da je ta osoba garant za takvo (ne) postupanje i da bi taj oblik kaznenog djela bio delictum proprium (jer bi se garantna kaznena djela trebala smatrati kao delicta propria zato što se traži posebno svojstvo počinitelja), jednako kao i dio inkriminacije koji se odnosi na činjenje.

Iz prikazanih primjera iz prakse uočava se kako je riječ o utaji zakonito stečenih prihoda iako zakonski tekst ne ograničava kazneno djelo utaje poreza na samo zakonito stečene prihode..$^{31}$ Tako Mršić navodi da ako se tumači na način da zakon ograničava kazneno djelo utaje poreza samo na zakonito stečene prihode, došlo bi do stavljanja u povoljniji položaj osoba koje obavljaju nezakonite djelatnosti² $s$ obzirom na to da ne bi postojala zakonska obveza prijavljivanja nezakonito stečenih prihoda. ${ }^{33}$ lako su prije u sudskoj praksi postojala drukčija rješenja pa je tako Županijski sud u Cospiću zaključio da „ostvaren prihod od eksploatacije, a koji se navodi u optužnom aktu, nije zakonito stečen prihod u smislu čl. 286. KZ-a pa u postupanju okr. nisu ostvarena obilježja bića kaznenog djela utaje poreza i drugih davanja iz čl. 286. KZ-a“". ${ }^{34}$ Činjenica je da danas prema Općemu poreznom zakonu postoji obveza plaćanja poreza i na stjecanje bez pravne osnove, tj. na "prihod, dohodak, dobit ili drugu procjenji-

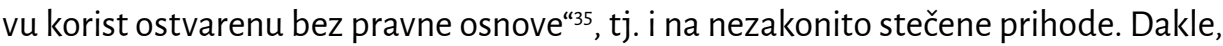
ako porezno tijelo utvrdi poreznu obvezu za nezakonito stečene prihode (čl. 11., st. 2. OPZ-a), u tom slučaju također može biti riječ o kaznenom djelu utaje poreza ako osoba ne plati taj porez. Međutim, potrebno je postojanje rješenja o razrezu poreza od porezne uprave kako bi bilo moguće počiniti kazneno djelo utaje poreza jer sve do donošenja rješenja o plaćanju poreza u takvim situacijama ne može se znati na što bi točno osoba bila dužna platiti porez i u kojem iznosu. U suprotnom, ako takva rješenja nema, nezakonitim stjecanjem imovinske koristi neće biti riječ o kaznenom djelu utaje poreza, nego o nekom drugom kaznenom djelu čija su obilježja ispunjena takvim protupravnim postupanjem počinitelja, pa se tako nezakonito pribavljena

sadržavaju li posljedicu u biću djela ili ne, također ulazilo u neprava kaznena djela nečinjenja jer je upravo posljedica (smanjenje ili neutvrđenje porezne ili carinske obveze) nužna za kvalifikaciju toga kaznenog djela kao nepravoga kaznenog djela nečinjenja. Također, glede prvog modaliteta djela to je i materijalno kazneno djelo jer mora doći do smanjenja ili neutvrđenja porezne ili carinske obveze, odnosno mora nastupiti posljedica. Za više vidi Novoselec, 2016, 124-127.

31 Turković; Novoselec; Crozdanić; Kurtović Mišić; Derenčinović; Bojanić; Munivrana Vajda; Mrčela; Nola; Roksandić Vidlička; Tripalo; Maršavelski, (Turkovići dr.), 2013, 329.

${ }_{32}$ Za nezakonite djelatnosti u obzir dolaze kaznena djela nedozvoljene proizvodnje (čl. 263. KZ-a) ili nedozvoljene trgovine (čl. 264. KZ-a).

${ }_{33}$ Mrš̌ić, 2008, 52-izvedeno iz odluke Vrhovnog suda Republike Hrvatske br. I Kž-223/73 od 19. ožujka 1974.

${ }^{34}$ Presuda Županijskog suda u Cospiću, Kž-89/07, od dana 18. travnja 2008., 2.

35 Čl. 11., st. 2. OPZ-a: „Ako je prihod, dohodak, dobit ili druga procjenjiva korist ostvarena bez pravne osnove, porezno tijelo utvrdit će poreznu obvezu u skladu s posebnim zakonom kojim se uređuje pojedina vrsta poreza." 
korist treba oduzeti u kaznenom postupku ex lege primjenom odredaba o oduzimanju protupravno stečene imovinske koristi. ${ }^{36}$ Inače predmetna odredba članka 11., stavka 2. OPZ-a vrlo je diskutabilna jer se može činiti da se na "mala vrata" legaliziraju nezakonite djelatnosti da bi država mogla na taj iznos naplatiti porez umjesto da se u takvim slučajevima sumnjive aktivnosti prijave nadležnim državnim tijelima, tj. državnom odvjetništvu ako se sumnja na kazneno djelo. Osoba koja je stekla neki prihod ili sl. nezakonitom djelatnošću, i ako je riječ o nekome kaznenom djelu (primjerice utaji poreza), u kaznenom postupku mora joj se oduzeti ta protupravno stečena imovinska korist, i to ex lege. S tim u vezi doći će do toga da joj država prvo naplaćuje porez na protupravno stečenu imovinsku korist, a potom joj tu korist i oduzima u kaznenom postupku, čime se osobu na neki način dvostruko „kažnjava“, a budući da je riječ o kaznenom djelu iz koristoljublja, može se počinitelju djela još izreći i sporedna novčana kazna (u tom bi slučaju ta osoba bila "trostruko kažnjena"). Jedanput naplatom poreza na imovinsku korist koja je pribavljena kaznenim djelom, drugi put $u$ kaznenom postupku oduzimanjem te protupravno stečene imovinske koristi, a treći put izricanjem sporedne novčane kazne. Takva rješenja nisu dopustiva. Ako je imovinska korist stečena bez pravne osnove, što upućuje na sumnju da je počinjeno kazneno djelo ili možda prekršaj (i u prekršajnom se postupku oduzima protupravno stečena imovinska korist) ${ }^{37}$, tada nadležna porezna tijela ne bi smjela razrezivati porez, nego prijaviti nadležnim pravosudnim tijelima, što ionako imaju obvezu učiniti. ${ }^{8}$ Postoji, međutim, mogućnost prema Općemu poreznom zakonu da se u slučajevima kada je „u kaznenom ili prekršajnom postupku pravomoćnom odlukom izrečena zaštitna mjera oduzimanja imovinske koristi ostvarene protupravnom radnjom, porezni akt kojim je utvrđena porezna obveza" poništi, ali samo na zahtjev poreznog obveznika. ${ }^{39}$ Ako nema tog zahtjeva, osobi će se oduzeti imovinska korist i porezni akt ostat će na snazi. Eventualno bi se trebala ostaviti mogućnost, ako se u kaznenom postupku ne oduzme protupravno stečena imovinska korist (zbog raznih razloga) ili osoba bude oslobođena optužbe, da (tek) tada porezna tijela utvrde, tj. razrežu porez.

Potrebno je istaknuti i sljedeće, ako se utvrdi da je počinitelj počinio kazneno djelo, cijeli će iznos stjecanja "bez pravne osnove“ završiti u državnom proračunu, a ne samo porez na taj iznos, što je sigurno bolji ishod za državu.

Poseban je oblik kaznenog djela utaje poreza ili carine i zlouporaba porezne olakšice ili carinske povlastice pa će se istom kaznom koja je propisana za temeljni oblik djela

\footnotetext{
Čl. 77. i 78. KZ-a.

7 Čl. 76. Prekršajnog zakona, NN, br. 107/07, 39/13,157/13,110/15, 70/17.

38 Čl. 8., st. 6. i čl. 123. OPZ-a.

39 Čl. 11., st. 3. OPZ-a.
} 
kazniti i osoba koja se „poreznom olakšicom ili carinskom povlasticom u iznosu većem od dvadeset tisuća kuna koristi suprotno uvjetima pod kojima ju je dobila“.40

Kvalificirani je oblik djela ako je došlo „do smanjenja ili neutvrđivanja porezne ili carinske obveze velikih razmjera" za što je propisano kažnjavanje od jedne do deset godina zatvora. ${ }^{41}$ Pojam „velikih razmjera" kaznenopravni je pojam i to je neodređena vrijednost kao obilježje kaznenog djela ${ }^{42}$, a što se podrazumijeva pod tim pojmom, prvo je određivao Vrhovni sud do stupanja na snagu novoga Kaznenog zakona 2013. godine ${ }^{43}$, a poslije je taj pojam bio definiran Kaznenim zakonom (čl. 87., toč. 27. $\mathrm{KZ}$-a) i utvrđen na iznos veći od $600.000,00 \mathrm{kn} .{ }^{44} \mathrm{Uz}$ sve navedeno, treba istaknuti da se uz osuđujuću presudu za utaju poreza oduzima i protupravno stečena imovinska korist da nitko ne bi mogao zadržati korist stečenu kaznenim djelom. Takvo postupanje dosljedno se provodi u praksi, što se vidi i iz presuda Općinskoga kaznenog suda u Zagrebu. ${ }^{45} \mathrm{Ako} \mathrm{je} \mathrm{postavljen} \mathrm{imovinskopravni} \mathrm{zahtjev} \mathrm{oštećenika,} \mathrm{on} \mathrm{ima} \mathrm{pra-}$ vo prednosti pred oduzimanjem imovinske koristi prema odredbama Zakona o kaznenom postupku (dalje u tekstu: ZKP). ${ }^{46}$ Međutim, nije određeno hoće li Republika Hrvatska, tj. proračun, imati pravo prednosti naplate svojeg potraživanja ako postoji više imovinskopravnih zahtjeva raznih oštećenika. Prema praksi Općinskoga kaznenog suda u Zagrebu proizlazi da će Republika Hrvatska biti samo jedna oštećenica u nizu te ni iz čega ne proizlazi da bi imala prioritet u namirenju svojeg potraživanja. ${ }^{47}$

40 Čl. 256., st. 2. KZ-a.

${ }_{41}$ Čl. 256., st. 3. KZ-a.

${ }^{42} \mathrm{Za}$ više o neodređenim vrijednostima vidi Garačić, 2013, 1-32, dostupno na http://www.vsrh.hr/ CustomPages/Static/HRV/Files/AGaracic_Pravna-shvacanja-o-neodredjenim_Opatija_2013.pdf (12.10.2017.).

${ }^{43}$ Na sjednici kaznenog odjela Vrhovnog suda Republike Hrvatske od 27. prosinca 2012. godine utvrđeno je da je "porezna obveza velikih razmjera" kada vrijednost porezne obveze prelazi $600.000,00$ kn. Garačić, 2013, 23-24. Dok se prije smatralo da je „porezna obveza velikih razmjera“ bila ako se prelazi iznos od $300.000,00 \mathrm{kn}$, što je bilo utvrđeno na sjednici kaznenog odjela Vrhovnog suda Republike Hrvatske iz 2006. godine suda (broj Su-IV-155/06-6). Caračić, 2013, 21.

${ }_{44}$ Čl. 87. toč. 27.: „Vrijednost je imovine, imovinske štete, imovinske koristi, porezne obveze i državne potpore velikih razmjera ako prelazi $600.000,00$ kuna. Razaranja prouzročena kaznenim djelima velika su ako prelaze $600.000,00$ kuna."

45 U presudi Općinskoga kaznenog suda u Zagrebu KO-2259/2011 sud u izreci navodi: „Na temelju članka 82. Kaznenog zakona, od okrivljenika se oduzima protupravna imovinska korist u iznosu od 85.350,74“. U presudi Općinskoga kaznenog suda u Zagrebu KO-214/15 sud u izreci navodi: „Na temelju čl. 82 KZ-a iz 1997. okrivljenom se oduzima imovinska korist ostvarena kaznenim djelom iz točke 1. presude u ukupnom iznosu od 577.248,01 kuna, koje je okrivljeni dužan uplatiti u korist državnog proračuna Republike Hrvatske u roku od 6 mjeseci od pravomoćnosti ove presude pod prijetnjom prisilne naplate."

${ }_{46}$ Čl. 181., st. 6. Zakona o kaznenom postupku, NN, br. 152/08, 76/09, 80/11, 91/12, 143/12, 56/13, 145/13, $152 / 14,70 / 17$.

47 U presudi Općinskoga kaznenog suda u Zagrebu KO-1392/13 sud u izreci navodi: „... okrivljenoj se izriče posebna obveza da popravi štetu počinjenu kaznenim djelima te je dužna u roku od 4 godine oštećenom društvu s ograničenom odgovornošću iz Zagreba platiti iznos od 92.838,33 kune; zatim oštećenom Erste Card Club d. d. platiti iznos od 66.506,27 kuna; oštećenom PBZ Card d. o. o. iz Zagreba 
Kaznenim djelom utaje poreza ili carine pruža se zaštita i sredstvima i proračunu Europske unije pa će počinitelj posebnog oblika toga kaznenog djela biti i osoba koja „umanji sredstva Europske unije“.$^{48}$ Uzroci su utaje poreza različiti i variraju od počinitelja do počinitelja kao i od vremena u kojem se poduzimaju takve radnje. ${ }^{49}$

\subsection{Počinitelj}

Kazneno djelo utaje poreza pripada na prvi pogled „u tzv. opća kaznena djela (delictum communium) “. ${ }^{50}$ To znači da počinitelj kaznenog djela utaje poreza može biti svaka fizička ili pravna osoba. Iz dijela teksta članka 256., st. 1. KZ-a u kojem se propisuje „tko s ciljem da on ili druga osoba potpuno ili djelomično izbjegne plaćanje poreza..." proizlazi da počinitelj toga kaznenog djela ne mora biti jedino porezni obveznik. Ne mora biti porezni obveznik, ali opet ne može biti bilo tko. To ipak mora biti osoba s posebnim svojstvima. Počinitelj je ponajprije porezni obveznik, ali može biti i druga osoba koja je ovlaštena davati podatke za poreznog obveznika na temelju kojih se razrezuje porez, stoga je to djelo, kao što je prije već navedeno, delictum proprium. Potrebno je istaknuti da svaki zakon kojim se uređuje plaćanje određene vrste poreza određuje tko se može smatrati poreznim obveznikom (čl. 14. OPZ-a). ${ }^{51}$ Primjerice ${ }^{52}$, Zakon o porezu na dodanu vrijednost (dalje u tekstu: ZPDV) ${ }^{53}$ određuje da je porezni obveznik "svaka osoba koja samostalno obavlja bilo koju gospodarsku djelatnost bez obzira na svrhu i rezultat obavljanja te djelatnosti“54, ali i „svaka osoba koja

platiti iznos od 42.553,73 kune; oštećenoj Republici Hrvatskoj platiti iznos od 414.314,06 kuna te drugom oštećenom društvu s ograničenom odgovornošću platiti iznos od 177.231,78 kuna“.

Može se pretpostaviti da je red namirenja sastavljen prema vremenu nastanka, tj. dospijeća obveze, ali se to ne može sa sigurnošću utvrditi.

Nadalje, u presudi Općinskoga kaznenog suda u Zagrebu KO-1293/14 u izreci se navodi: „... okrivljeni na ime imovinskopravnog zahtjeva dužan je isplatiti oštećenoj Republici Hrvatskoj zastupanoj po Općinskom državnom odvjetništvu u Zagrebu, Građansko-upravni odjel iznos od 160.23,09 kuna." Slično Općinski kazneni sud u Zagrebu izriče i u presudi K-354/15: „... I okrivljeni i ll okrivljeni dužni su u roku od 3 godine Republici Hrvatskoj platiti ukupan iznos od 141.998,93 kune na način da je svaki okrivljenik dužan u navedenom roku platiti jednu polovicu tog iznosa, tj. po 70.999,46 kuna“.

${ }_{48}$ Čl. 256., st. 4. KZ-a.

49 Šimović; Rogić Lugarić; Cindori, 2007, 599.

50 Juranić, 1965, 27.

51 Čl. 14. OPZ-a: „Porezni obveznik svaka je osoba koja je kao takva određena zakonom kojim se uređuje pojedina vrsta poreza."

${ }_{52}$ S obzirom na temu rada i opseg koji rad ne bi smio prijeći, nije moguće navesti sve zakone koji uređuju poreznu materiju i osobe koje se trebaju smatrati poreznim obveznicima prema tim zakonima. $\mathrm{U}$ tom kontekstu navest će se samo, primjerice, tko se može smatrati, odnosno tko se neće smatrati poreznim obveznikom prema Zakonu o porezu na dodanu vrijednost i Zakonu o porezu na dobit.

${ }_{53}$ Zakon o porezu na dodanu vrijednost, NN, br. 73/2013, 99/2013, 148/2013, 153/2013, 143/2014, 115/2016.

${ }_{54}$ Čl. 6., st. 1. ZPDV-a.

Za više o porezu na dodanu vrijednosti o tome tko je porezni obveznik plaćanja tog poreza vidi Cindori; Pilipović; Kalčić, 2015, 47-53. 
povremeno isporučuje nova prijevozna sredstva iz članka 4., stavka 3. ovoga Zakona koja kupcu otpremi ili preveze prodavatelj, sam kupacili druga osoba za njihov račun na područje druge države članice.. ${ }^{55}$ Zakon određuje i tko se u pravilu neće smatrati poreznim obveznikom, primjerice „tijela državne vlasti, tijela državne uprave, tijela i jedinice lokalne i područne (regionalne) samouprave, komore te druga tijela sjavnim ovlastima i u slučaju kada ubiru pristojbe, naknade i druga plaćanja u vezi s obavljanjem djelatnosti ili transakcija u okviru svog djelokruga ili ovlasti ${ }^{456}$ uz iznimku da će se ipak i oni smatrati poreznim obveznicima ako „bi obavljanje tih djelatnosti, kao da nisu porezni obveznici, dovelo do znatna narušavanja načela tržišnog natjecanja kod obavljanja takvih djelatnosti ili transakcija, ta se tijela smatraju poreznim obveznicima u vezi s tim djelatnostima ili transakcijama". ${ }^{57}$ Zakon o porezu na dobit (dalje u tekstu: ZPD) ${ }^{58}$ određuje da je porezni obveznik „trgovačko društvo i druga pravna i fizička osoba rezident Republike Hrvatske koja gospodarsku djelatnost obavlja samostalno, trajno i radi ostvarivanja dobiti, dohotka ili prihoda ili drugih gospodarskih procjenjivih koristi“ ${ }^{459}$ kao i ,tuzemna poslovna jedinica inozemnog poduzetnika (nerezident)“ ${ }^{4}$, „fizička osoba koja ostvaruje dohodak prema propisima o oporezivanju dohotka ako izjavi da će plaćati porez na dobit umjesto poreza na dohodak" ${ }^{\text {"61 }}$, zatim "fizička osoba koja ostvaruje dohodak od obrta i s obrtom izjednačenih djelatnosti prema propisima o porezu na dohodak: ako je u prethodnome poreznom razdoblju ostvario ukupni primitak veći od 3.000.000,00 kuna, ako ispunjava dva od sljedeća tri uvjeta, ako je u prethodnome poreznom razdoblju ostvario dohodak veći od 400.000,00 kuna, ili ako ima dugotrajnu imovinu u vrijednosti većoj od 2.000.000,00 kuna, ili ako je u prethodnome poreznom razdoblju prosječno zapošljavao više od 15 radnika". ${ }^{62}$ Zakon određuje slično kao i Zakon o PDV-u tko se neće smatrati pa to ponajprije neće biti „tijela državne uprave, tijela područne (regionalne) samouprave, tijela lokalne samouprave i Hrvatska narodna banka", ${ }^{63}$ a zanimljivo je da se obveznicima neće smatrati ni „državne ustanove, ustanove jedinica područne (regionalne) samouprave, ustanove jedinica lokalne samouprave, državni zavodi, vjerske zajednice, političke stranke, sindikati, komore, udruge, umjetničke udruge, dobrovoljna vatrogasna društva, zajednice tehničke kulture, turističke zajednice, sportski klubovi, sportska društva i savezi, zaklade i fundacije“. ${ }^{64}$

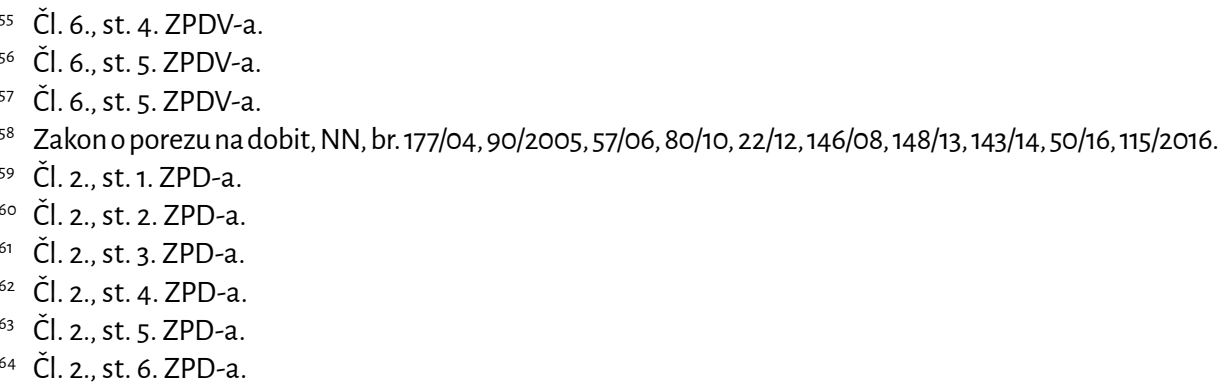


Neovisno o činjenici što je porezni obveznik dužan prijaviti podatke o svojim zakonito stečenim dohodcima, predmetima ili o drugim činjenicama od kojih zavisi utvrđenje visine porezne obveze i što bi izbjegavanje plaćanja poreza bilo u njegovu interesu, ta činjenica nije sama po sebi dovoljna da se poreznog obveznika automatski poistovjeti s počiniteljem toga kaznenog djela ${ }^{65}$ jer po dikciji norme, kao što je već navedeno, to može biti i druga osoba koja nije porezni obveznik. Počinitelj je tako i osoba koja u ime drugoga podnosi prijavu s lažnim podatcima da bi ta druga osoba izbjegla plaćanje poreza pa je, primjerice, prema praksi Općinskoga kaznenog suda u Zagrebu (KO-93/15 i KO-1293/14) to direktor društva kada ne plaća porez koji bi trebalo platiti društvo, ali to može biti i poslodavac, osoba koja pod tuđim imenom obavlja poslovnu djelatnost, a koja ga obvezuje na podnošenje prijave ${ }^{66}$, računovođa kao ovlaštena osoba kod poslodavca koja je zadužena za isplatu plaća i uplatu poreza i prireza i dr. Da bi ta osoba bila počinitelj, mora biti svjestan da su podatci koje daje ovlaštenim poreznim tijelima netočni ili nepotpuni i da to može dovesti do neplaćanja poreza ili plaćanja manjeg poreza od onoga koji bi trebalo platiti. ${ }^{67}$

Iz svega navedenog, uz rečeno, daje se zaključiti i sljedeće. Osobe koje bi se inače smatrale pomagačima (prema odredbama općeg dijela Kaznenog zakona; čl. 38. KZa) $u$ kaznenom djelu utaje poreza ili carine, njegovom su normom izrijekom određeni kao počinitelji toga kaznenog djela.

Drugi modalitet, kao što je prije navedeno, može počiniti samo osoba koja je obvezna prijaviti činjenice, predmete i dr. na temelju kojih se treba razrezati porez, a to je ponajprije porezni obveznik kao garant koji je odgovoran i dužan spriječiti zakonom propisanu posljedicu, tj. spriječiti potpuno ili djelomično izbjegavanje plaćanja poreza ili carine, ali može biti i druga osoba, primjerice direktor, računovođa i sl.

\subsection{Oblik krivnje, subjektivno obilježje i objektivni uvjet kažnjivosti}

Da bi kod utaje poreza bila riječ o kaznenom djelu, a ne o prekršaju, mora biti ispunjen objektivni uvjet kažnjivosti kao materijalno-pravna pretpostavka kažnjivosti, tj. iznos utajenog poreza ili carine mora biti veći od 20.000,00 kuna ${ }^{68}$, i djelo mora biti počinjeno s namjerom (izravnom ili neizravnom), a počinitelj mora postupati s ciljem izbjegavanja (potpunog ili djelomičnog) plaćanja poreza. ${ }^{69}$ Postojanje

\footnotetext{
65 Juranić, 1965, 28.

${ }^{66}$ Mršić, 2008, 52.

${ }_{67}$ Primjerice, šef računovodstva prijavljuje platnu listu za nekog zaposlenika u društvu (ustanovi) iako zna da se na platnoj listi nalaze netočni podatci jer je ta osoba imala puno veća primanja od prijavljenih i navedenih na platnoj listi pa time uplaćuje manji porez (prirez).

68 Matković, 2013, 164.

69 Za više o namjeri vidi Horvatić; Derenčinović; Cvitanović, 2017, 94-105 i Novoselec, 2016, 220-230.
} 
namjere u svakom se pojedinom slučaju procjenjuje pa se ne može pretpostaviti da namjera automatski postoji, nego se mora utvrditi prema svim okolnostima slučaja. Za prekršajnu odgovornost dovoljan je i nehaj, tj. povreda dužne pažnje. ${ }^{70}$ Općinski kazneni sud u Zagrebu u predmetu KO-2259/2011 naveo je da je „jedino logično objašnjenje za podnošenje neistinitih prijava pribavljanje imovinske koristi koja je ostvarena time što je porez plaćen u iznosu nižem od realnog... da je svjestan protupravnosti svog ponašanja, ali je unatoč tome to djelo htio kao takvo" ${ }^{\text {"1 }}$, tj. da je počinitelj djelo počinio s namjerom.

Inače je u teoriji i praksi vrlo sporno s kojim se oblikom krivnje može postupati kada zakonski opis djela sadržava subjektivno obilježje "s ciljem“ ili „u cilju“ (ili druga subjektivna obilježja kao, primjerice, postojanje „obijesti“ kod kaznenog djela obijesne vožnje čl. 226. KZ-a). Cilj je potpunog ili djelomičnog izbjegavanja plaćanja poreza (ili carine) subjektivno obilježje kaznenog djela $^{72}$, a taj se cilj može ostvarivati za sebe ili za neku drugu osobu. Takva kaznena djela nazivaju se još i ciljnim kaznenim djelima (Absichtsdelikte). ${ }^{73}$ Kako Munivrana Vajda navodi, kod „tih delikata subjektivni element" ${ }^{\text {"74 }}$ u pravilu „prelazi objektivno biće kaznenog djela i odnosi se na neki daljnji, budući cilj radnje ili buduće nastupanje opisane posljedice ${ }^{475}$ koje nije sadržano u biću tog djela. Međutim, konkretno kod kaznenog djela utaje poreza ili carine ostvarenje se cilja, tj. posljedica, nalazi u biću djela (izbjegavanje plaćanja ili plaćanje manjeg poreza).

\footnotetext{
70 Matković, 2013, 162.

${ }^{71}$ U presudi Općinskoga kaznenog suda u Zagrebu K-643/2015 počinitelj je u svojstvu direktora društva s ograničenom odgovornošću u nakani da istom društvu pribavi nepripadnu materijalnu dobit u znatnom iznosu na štetu proračuna počinio kazneno djelo utaje poreza ili carine prema članku 256. stavku 1. KZ-a tako da nije prijavljivao činjenice koje su od utjecaja na utvrđivanje porezne obveze te je sud također utvrdio da je počinitelj postupao s izravnom namjerom: „Čineći ovo djelo, okrivljeni je postupao s izravnom namjerom znajući za sve te bitne elemente bića ovog kaznenog djela, htijući da se svi ti bitni elementi ostvare, a što se i dogodilo." Vidi još i presudu Općinskog kaznenog suda u Zagrebu br. KO-1293/14.

72 Subjektivna obilježja djela nalaze se još kod kaznenog djela krađe (čl. 228., st. 1. KZ-a) kod kojeg da bi bila riječ o tom djelu mora postojati „cilj protupravnog prisvajanja“, ali i brojnih drugih kaznenih djela, primjerice, terorizma (čl. 97. KZ-a), protupravnog oduzimanja slobode (čl. 136. KZ-a), otmice (čl. 137. KZ-a), povrede tajnosti pisama i drugih pošiljaka (čl. 142. KZ-a), razbojništva (čl. 230. KZ-a) i dr.

73 Za više vidi Horvatić; Derenčinović; Cvitanović, 2017, 154. i Muniurana Vajda, 2011, 83, 242; i Novoselec, 2016, 113-114. i Schönke; Schröder, 1997, 1717.

Kod tih kaznenih djela moguće je razlikovanje formalnog i materijalnog dovršenja djela. Za više o formalnom i materijalnom dovršenju djela vidi Horvatić; Derenčinović; Cvitanović, 2017, 154.

74 Munivrana Vajda, 2011, 83.

75 Munivrana Vajda, 2011, 83. i vidi više o tome u Jescheck, H.-H.; Weigend, T. (1996). Lehrbuch des Strafrecht, Allgemeiner Teil, Duncker \& Humblot, Berlin, 297-298, 319 u Munivrana Vajda, 2011, 83.
} 
Dio teoretičara i praktičara (Zlatariç̄ $\hat{c}^{76}$, Bačić, Šeparoviç77 i Pavlović) ${ }^{78}$ bio je stava da je takva djela čiji zakonski opisi i biće djela sadržavaju subjektivna obilježja, pojmovno određena kao postupanje „u cilju“ ili „s ciljem“ (ili tada namjerom) ${ }^{79}$, moguće počiniti isključivo s izravnom namjerom jer počinitelj, čim postupa s nekim ciljem, mora biti svjestan obilježja djela, tj. znati da čini to djelo i htjeti njegovo počinjenje (izravna namjera - čl. 28., st. 2. KZ-a). Međutim, to je stajalište u novije vrijeme napušteno jer intelektualna sastavnica namjere obuhvaća sva objektivna obilježja djela, dok su subjektivna isključena, pa je zauzeto shvaćanje kako se i takva djela mogu počiniti ne samo s izravnom nego i neizravnom namjerom (npr. Novoselec i Bojanic ${ }^{80}, C^{2} i t a n o v i c^{81}$, Dragičević Prtenjača ${ }^{82}$ ). Pitanje je konkretno kod ovoga kaznenog djela može li se i ono počiniti i s neizravnom namjerom. Hipotetski, argumentacije radi, ako je osoba koja daje podatke radi utvrđivanja poreza svjesna da daje nepotpune ili netočne podatke i pristaje na to da time čini ovo kazneno djelo (utaje poreza) da bi izbjegla plaćanje poreza, jasno je da može biti počinitelj toga kaznenog djela. U tom se kontekstu može zaključiti kako je moguće i njega počiniti i s neizravnom namjerom.

Clede objektivnog uvjeta kažnjivosti spornim se u praksi pokazalo i pitanje je li svako neplaćanje poreza u iznosu većem od 20.000,00 kn automatski kazneno djelo ili ipak to ne bi bio slučaj. O tome je odlučivao i Vrhovni sud Republike Hrvatske (dalje u tekstu: VSRH) u dva predmeta te je zauzeo stajalište da "samo propuštanje isplate obveza prema proračunu, nakon njihova prijavljivanja, a bez prethodnog davanja netočnih ili nepotpunih podataka o okolnostima o kojima ovisi utvrđenje porezne obveze, više nije kazneno djelo" ${ }^{~}{ }^{83}$ I $z$ toga proizlazi da sama činjenica nemogućnosti plaćanja poreza bez namjere utaje (davanja pogrešnih i nepotpunih podataka i dr.) nije kazneno djelo, nego je takvo postupanje ostavljeno prekršajnoj zoni, pa čak i u onim slučajevima u kojima iznos premašuje zakonom propisani limit $(20.000,00 \mathrm{kn})$

\footnotetext{
${ }^{76}$ Za više o namjeri (tadašnjem umišljaju) i subjektivnom obilježju kod neprijateljske propagande (čl. 118. Krivičnog zakonika) vidi Zlatarić, 1958, 35-36.

77 Za više o namjeri i subjektivnom obilježju djela kod krađe (čl. 130. KZH-a koji je tada bio malo drukčiji jer se tražilo postupanje "s ciljem" pribavljanja protupravne imovinske koristi, a ne kao danas "s ciljem" protupravnog prisvajanja) vidi Bačić; Šeparović, 1992, 222.

${ }_{78}$ Za više o namjeri kod kaznenog djela krađe (čl. 216. KZ-a iz 1997.) vidi Bačić; Pavlović, 2001, 214.

79 U starijoj kaznenopravnoj literaturi zakonski opisi znali su sadržavati izraz "namjeru“ (npr. kod kaznenog djela neprijateljske propagande čl. 118.) koje bi danas odgovaralo izrazu „u cilju“ ili „s ciljem“. Tadašnja je namjera terminološki bila određena kao „umišljaj“, dok je riječ „namjera“ označavala subjektivno obilježje kaznenog djela. Zlatarić, 1958, 35-36.

Takva podjela postoji i danas u kaznenom pravu Srbije. Za više vidi Škulić, 2017, 415, bilj. 63.

${ }^{80}$ Za više o namjeri i subjektivnom obilježju djela kod krađe (čl. 216. KZ-a 1997.) vidi Bojanić; Cvitanović; Derenčinović; Grozdanić; Kurtović; Novoselec; Turković, (Novoselec idr.), 2007, 221-222.

81 Za više o namjeri kod kaznenog djela krađe (čl. 228. KZ-a) vidi Cvitanović u Horvatić; Derenčinović; Cvitanović, 2018, 304.

82 Za više o namjeri i obijesti (kao subjektivnom obilježju) kod obijesne vožnje (čl. 226. KZ-a) vidi Dragičević Prtenjača u Horvatić; Derenčinović; Cvitanović, 2018, 278 i 283.

83 VRSH, Kž 818/2012, od dana19. rujna 2012., str. 9. i VRSH, Kž 882/12, od dana 22. rujna 2015., 6.
} 
za kazneno djelo utaje poreza ili carina. Jednostavno rečeno, da bi bila riječ o kaznenom djelu utaje poreza ili carina, mora postojati namjera utaje ili prijevare s ciljem izbjegavanja određivanja ili plaćanja porezne obveze, a iznos utajenog poreza mora biti veći od 20.000,00 kuna.

Objektivni se uvjeti kažnjivosti u dogmatici dijele na prave i neprave. ${ }^{84}$ Konkretno je kod kaznenog djela utaje poreza ili carine riječ o (nepravom) objektivnom uvjetu kažnjivosti kojim se utemeljuje kažnjivost. ${ }^{85}$ Naime, zanimljivost je toga uvjeta da on nije pokriven nijednim oblikom krivnje počinitelja (ni namjerom ni nehajem) i nije riječ o posljedici kaznenog djela. Drugim riječima, počinitelj se toga kaznenog djela za njega kažnjava samo zato što je taj uvjet ostvaren (naravno, ako su ispunjena i druga obilježja bića kaznenog djela), a počinitelj ne mora imati nikakvu svijest o tome ni to htjeti ili barem pristati na to da je utaja koju čini veća od 20.000,00 kn. ${ }^{86}$

Zašto se zakonodavac opredijelilo za imovinski cenzus od 20.000,00 kn (kao objektivan uvjet kažnjivosti), ostaje pitanje. Naime, u Obrazloženju Konačnog prijedloga Kaznenog zakona stoji da je iznos od 20.000,00 kuna određen zbog usuglašavanja s Konvencijom o zaštiti financijskih interesa Europskih zajednica (tzv. Konvencija PIF; dalje u tekstu: Konvencija PIF) ${ }^{87}$, preciznije, s njezinim čl. 2., st. 1. i 2. prema kojem se Konvencija odnosi samo na teže oblike prijevara ${ }^{88}$ (u koje ulaze i utaje poreza i carina) veće od 4.000,00 eura. ${ }^{89} \mathrm{U}$ Konvenciji PIF stoji da je potrebno za takve teže oblike

84 Pravi suzuju kažnjivost, a nepravi je utemeljuju. Za više o objektivnim uvjetima kažnjivosti i razlikovanju pravih od nepravih Horvatić; Derenčinović; Cvitanović, 2017, 133, i Novoselec, 2016, 259-260.

O objektivnim uvjetima kažnjivosti bilo je govora dugi niz godina za kazneno djelo izazivanja prometne nesreće (čl. 227. KZ-a), je li kod toga kaznenog djela riječ o objektivnom uvjetu kažnjivosti (nastup teške tjelesne ozljede ili imovinske štete velikih razmjera) ili o posebnom tipu bića kaznenog djela tzv. mixtum compositum kod kojeg paralelno postoji kaznenog djelo ugrožavanja (sigurnosti prometa) i povređivanja (tijela ili imovine). Horvatić; Derenčinović; Cvitanović, 2018, 289, i Horvatić; Šeparovići sur., 1999, 356.

${ }^{85}$ Horvatić; Derenčinović; Cvitanović, 2017, 133, i Novoselec, 2016, 259-260.

${ }^{86}$ Za više vidi Horvatić; Derenčinović; Cvitanović, 2017, 133.

Objektivni uvjeti kažnjivosti nalaze se i kod drugih kaznenih djela, primjerice kod kaznenog djela neprijavljivanja pripremanja kaznenog djela (čl. 301. KZ-a), a koji se odnose na to da je riječ o tome kaznenom djelu samo ako ono bude „pokušano ili počinjeno" (objektivni uvjet kažnjivosti), kao i kod kaznenog djela sudjelovanja u samoubojstvu (čl. 114., st. 1. KZ-a), kod kojeg se traži ostvarenje istoga objektivnog uvjeta kažnjivosti (da djelo bude „pokušano ili počinjeno") kako bi bila riječ o tome kaznenom djelu. Također, nalazi se kod kaznenog djela sudjelovanja u tučnjavi (čl. 122., st. 1. KZ-a) kod kojeg je nastup teške tjelesne ozljede ili smrti neke osobe upravo (nepravi) objektivni uvjet kažnjivosti. U tim je slučajevima biće kaznenog djela uže od zakonskog opisa kaznenog djela.

${ }_{87}$ Za više vidi Konvenciju o zaštiti financijskih interesa Europskih zajednica koja je donesena 1995. godine, a stupila na snagu tek 2002., dostupnu na https://eur-lex.europa.eu/legal-content/HR/TXT/ PDF/?uri=CELEX:41995A1127(03)\&from=EN (5.6.2018.).

${ }^{88}$ Ozbiljnom prijevarom smatra se prijevara koja uključuje određivanje nekoga minimalnog iznosa, a koji određuje svaka država za sebe s tim da taj minimalni iznos ne smije biti određen na iznos koji prelazi 50.000,00 eura. Čl. 2., st. 1. Konvencije PIF.

89 Obrazloženje Konačnog prijedloga Kaznenog zakona, listopad 2011., PZE 866, 236. i Turković i dr., 2013, 329. 
prijevara propisati učinkovite, razmjerne i odvraćajuće kazne, odnosno kazne s propisanom kaznom zatvora koje bi u slučajevima ozbiljnih prijevara "mogle dovesti do izručenja“" ${ }^{\circ}$ Drugim riječima, obveza sankcioniranja naznačenim sankcijama u toj konvenciji ne postoji za lakše oblike prijevara (time i utaja poreza i carina) čiji je ukupan iznos manji od 4.000,00 eura i ne uključuju posebno ozbiljne okolnosti u skladu s njezinim zakonodavstvom. ${ }^{91}$ Upravo je u vezi s iznesenim potrebno uputiti kritiku tako određenom iznosu od 20.000,00 kn kod kaznenog djela utaje poreza i carine jer je taj iznos manji od 4.000,00 eura. Bilo bi više u skladu s navedenim obrazloženjem propisati veći imovinski cenzus od okvirno $30.000,00 \mathrm{kn}(7,5 \times 4.000){ }^{92}$

\subsection{Pokušaj}

Važno je napomenuti da počinitelj mora postupati s namjerom (izravnom i neizravnom) i c ciljem izbjegavanja plaćanja poreza ili carine uz to što se taj cilj (djelomično ili potpuno izbjegavanje plaćanja poreza) mora i realizirati i to $u$ iznosu većem od 20.000 kuna da bi djelo bilo potpuno dovršeno. Ako nije došlo do izbjegavanja (potpunog ili djelomičnog) plaćanja poreza (kao posljedice kod toga kaznenog djela), djelo će ostati u pokušaju. Pokušaj je kažnjiv i za temeljni oblik djela (st. 1.) i za sve ostale oblike (st. 2., st. 3. i st. 4.) zbog primjene općih pravila o kažnjivosti pokušaja iz općeg dijela Kaznenog zakona (čl. 34., st. 1. KZ-a).

\subsection{Statistički podatci}

Statistički gledano, kazneno djelo utaje poreza ili carine ${ }^{93}$ relativno je slabo zastupljeno u sudskoj praksi prema podatcima Državnog zavoda za statistiku (dalje u tekstu: DZS). Za kaznena djela protiv gospodarstva u 2016. godini bilo je osuđeno ukupno 746 osoba od čega 48 za temeljni oblik kaznenog djela utaje poreza ili carine (čl. 256., st. 1. KZ-a), odnosno ukupno 59 osoba za temeljeni i kvalificirani oblik kaznenog djela utaje poreza ili carine (čl. 256., st. 1. i 3. KZ-a), a što je 8 \% gospodarskog kriminala, odnosno 0,4 \% ukupna kriminala u 2016. godini.94

\footnotetext{
90 Čl. 2., st. 1. Konvencije PIF.

91 Čl. 2., st. 2. Konvencije PIF.

92 Iznos od 30.000,00 kn više bi odgovarao obrazloženju Konačnog prijedloga Kaznenog zakona jer je srednji tečaj eura prema HNB-u (Hrvatskoj narodnoj banci) u listopadu bio 7,46 ili 7,5 (7,5 × 4.000 = 30.000,00 kn). Informacije dostupne na http://old.hnb.hr/tecajn/h291011.htm (6.6.2018.).

Potrebno je istaknuti da je imovinski cenzus kod kaznenog djela utaje poreza i drugih davanja (čl. 286. KZ-a iz 1997.) bio 10.000,00 kn.

${ }_{93}$ Potrebno je skrenuti pozornost na to da je do 2013. godine, kada na snagu stupa novi (danas važeći) Kazneni zakon, to kazneno djelo tadašnjeg naziva utaja poreza i drugih davanja (čl. 286. KZ-a iz 1997.) bilo drukčije uređeno i odnosilo se i na druga davanja, a ne samo na porez i carine.

94 Izvješće DZS-a, br. 1605/2017, Punoljetni počinitelji kaznenih djela, prijave, optužbe i osude u 2016., 175.
} 
Tablica 1. Ukupan broj počinitelja kaznenih djela i broj počinitelja za kazneno djelo utaje poreza ili carine (čl. 256. KZ-a) 2010. - 2016. god.95

\begin{tabular}{|c|c|c|c|c|c|c|c|}
\hline \multicolumn{7}{|c|}{$\begin{array}{c}\text { Ukupan broj počinitelja kaznenih djela i broj počinitelja } \\
\text { za kazneno djelo utaje poreza ili carine 2010. - 2016. }\end{array}$} \\
\hline $\begin{array}{c}2016 . \\
\text { godina }\end{array}$ & $\begin{array}{c}2015 . \\
\text { godina }\end{array}$ & $\begin{array}{c}2014 . \\
\text { godina }\end{array}$ & $\begin{array}{c}2013 . \\
\text { godina }\end{array}$ & $\begin{array}{c}2012 . \\
\text { godina }\end{array}$ & $\begin{array}{c}2011 . \\
\text { godina }\end{array}$ & $\begin{array}{c}2010 . \\
\text { godina }\end{array}$ \\
\hline $\begin{array}{c}\text { Ukupno } \\
\text { osuđenih u } \\
\text { toj godini }\end{array}$ & 13.412 & 12.552 & 14.888 & 16.617 & 20.548 & 23.389 & 24.430 \\
\hline $\begin{array}{c}\text { Ukupno } \\
\text { osuda, čl. } \\
\text { 256. KZ-a }\end{array}$ & $\begin{array}{c}59 \\
(7 \text { žena) }\end{array}$ & $\begin{array}{c}73 \\
(14 \text { žena) }\end{array}$ & $\begin{array}{c}82 \\
(11 \text { žena) }\end{array}$ & $\begin{array}{c}51 \\
(7 \text { žena) }\end{array}$ & $\begin{array}{c}24 \\
(6 \text { žena) }\end{array}$ & $\begin{array}{c}29 \\
(3 \text { žene) })\end{array}$ & $\begin{array}{c}31 \\
(3 \text { žene })\end{array}$ \\
\hline Postotak & $0,44 \%$ & $0,58 \%$ & $0,55 \%$ & $0,30 \%$ & $0,12 \%$ & $0,12 \%$ & $0,13 \%$ \\
\hline
\end{tabular}

349 osoba bilo je ukupno osuđeno za sve oblike kaznenog djela utaje poreza ili carine (čl. 256. KZ-a) od 2010. do $2016 .{ }^{96}$ Treba primijetiti relativno velik udio žena (prosječno oko $15 \%)^{97}$ u počinjenju kaznenog djela utaje poreza ili carine u promatranome sedmogodišnjem razdoblju od njihova uobičajenog sudjelovanja u ukupnu kriminalu (s oko $10 \%$ ). ${ }^{98}$ Međutim, potrebno je napomenuti da je u konkretnom razdoblju (2010. -2016.) taj postotak sudjelovanja (udjela) žena u ukupnu kriminalu nešto veći i iznosi oko $11 \% .^{99}$

\footnotetext{
95 Tablicu su izradili autori prema podatcima DZS-a.

96 Izvješće, br. 1576/2016, Zagreb, 2016., Punoljetni počinitelji kaznenih djela, prijave, optužbe i osude u 2015., 146; Izvješće, br. 1551/2015, Zagreb, 2015., Punoljetni počinitelji kaznenih djela, prijave, optužbe i osude u 2014., 128; Izvješće, br. 1528/2014, Zagreb, 2014., Punoljetni počinitelji kaznenih djela, prijave, optužbe i osude u 2013., 126; Izvješće, br. 1504/2013, Zagreb, 2013., Punoljetni počinitelji kaznenih djela, prijave, optužbe i osude u 2012., 116; Izvješće, br. 1478/2012, Zagreb, 2012., Punoljetni počinitelji kaznenih djela, prijave, optužbe i osude u 2011., 126; Izvješće, br. 1451/2011, Zagreb, 2011., Punoljetni počinitelji kaznenih djela, prijave, optužbe i osude u 2010., 152. Dostupno na http://www.dzs.hr/ (12.10.2017.).

97 Izračun su napravili autori prema podatcima DZS-a.

Tako je u predmetu KO-1392/13 vođenom pri Općinskome kaznenom sudu u Zagrebu od 2010. godine do danas zabilježena samo jedna presuda (od ukupno osam) protiv počiniteljice koja je uz počinjenje ostalih kaznenih djela (prijevara u gospodarskom poslovanju, zlouporaba čeka i kreditne kartice, povreda vođenja trgovačkih i poslovnih knjiga, prijevara) počinila i kazneno djelo utaje poreza ili carine. Osuđena u svojstvu direktorice jednog društva s ograničenom odgovornošću nije od 1. siječnja 2011. do 31. svibnja 2012. u Zagrebu obračunala, prijavila ni uplatila iznos poreza na dodanu vrijednost na oporezive primitke od poslovne djelatnosti trgovinom na malo i veliko na tuzemnom tržištu njezina dioničkog društva čime je oštetila državni proračun Republike Hrvatske za iznos od 414.314,06 kuna.

98 Derenčinović; Cetoš, 2008, 164.

99 Izvješće DZS-a, br. 1605/2017., 13.
} 
Tablica 2. Punoljetni počinitelji kaznenih djela - osude za kazneno djelo utaje poreza ili carine (čl. 256. KZ-a) 2010. - 2016. god. ${ }^{100}$

\begin{tabular}{|c|c|c|c|c|c|c|c|}
\hline \multicolumn{7}{|c|}{ kazneno djelo utaje poreza ili carine (čl. 256. KZ-a) } \\
\hline & $\begin{array}{c}2016 . \\
\text { godina }\end{array}$ & $\begin{array}{c}2015 . \\
\text { godina }\end{array}$ & $\begin{array}{c}2014 . \\
\text { godina }\end{array}$ & $\begin{array}{c}2013 . \\
\text { godina }\end{array}$ & $\begin{array}{c}2012 . \\
\text { godina }\end{array}$ & $\begin{array}{c}2011 . \\
\text { godina }\end{array}$ & $\begin{array}{c}2010 . \\
\text { godina }\end{array}$ \\
\hline $\begin{array}{c}\text { Čl. 256., } \\
\text { st. 1. KZ-a }\end{array}$ & $48(81 \%)$ & $61(84 \%)$ & $79(96 \%)$ & $46(91 \%)$ & 24 & 29 & 31 \\
\hline $\begin{array}{c}\text { Čl. 256., } \\
\text { st. 2. KZ-a }\end{array}$ & $/$ & $7(9,6 \%)$ & $2(2,4 \%)$ & $/$ & $/$ & $/$ & $/$ \\
\hline $\begin{array}{c}\text { Čl. 256., } \\
\text { st. 3. KZ-a }\end{array}$ & 11 & $5(6,8 \%)$ & $1(1,2 \%)$ & $5(9,8 \%)$ & $* 101$ & $*$ & $*$ \\
\hline Ukupno osuda & $\begin{array}{c}59 \\
(7 \text { žena) }\end{array}$ & $\begin{array}{c}73 \\
(14 \text { žena })\end{array}$ & $\begin{array}{c}82 \\
(11 \text { žena) }\end{array}$ & $\begin{array}{c}51 \\
(7 \text { žena) }\end{array}$ & $\begin{array}{c}24 \\
(6 \text { žena) }\end{array}$ & $\begin{array}{c}29 \\
(3 \text { žene) }\end{array}$ & $\begin{array}{c}31 \\
(3 \text { žene) }\end{array}$ \\
\hline
\end{tabular}

Iz predmetne tablice proizlazi da se najviše čini temeljni oblik kaznenog djela utaje poreza ili carine, oko $90 \%$, dok se kvalificirani oblik (smanjenje/neutvrđenje porezne/ carinske obveze velikih razmjera, tj. više od 600.000,00 kn) čini manje, oko $9 \%$. Poseban oblik utaje poreza ili carine, korištenje poreznih ili carinskih olakšica, suprotno dobivenim uvjetima relativno je slabo zastupljen, najviše ga je bilo 2015. godine kada je iznosio 9,6\% od ukupno počinjenih kaznenih djela utaje poreza ili carine te godine.

Tablica 3. Sankcije izrečene punoljetnim počiniteljima za kazneno djelo utaje poreza ili carine (čl. 256. KZ-a) 2010. - 2016. god. ${ }^{102}$

\begin{tabular}{|c|c|c|c|c|c|c|c|}
\hline \multicolumn{7}{|c|}{$\begin{array}{c}\text { Punoljetni počinitelji kaznenih djela-izrečene sankcije } \\
\text { za kazneno djelo utaje poreza ili carine (čl. 256. KZ-a) }\end{array}$} \\
\hline & $\begin{array}{c}2016 . \\
\text { godina }\end{array}$ & $\begin{array}{c}2015 . \\
\text { godina }\end{array}$ & $\begin{array}{c}2014 . \\
\text { godina }\end{array}$ & $\begin{array}{c}2013 . \\
\text { godina }\end{array}$ & $\begin{array}{c}2012 . \\
\text { godina }\end{array}$ & $\begin{array}{c}2011 . \\
\text { godina }\end{array}$ & $\begin{array}{c}2010 . \\
\text { godina }\end{array}$ \\
\hline Uvjetna osuda & 46 (78 \%) & $60(82 \%)$ & $67(81 \%)$ & $46(90 \%)$ & $22(92 \%)$ & $26(90 \%)$ & $29(94 \%)$ \\
\hline $\begin{array}{c}\text { Kazna zatvora } \\
3-6 \text { mj. }\end{array}$ & - & 1 & 1 & - & - & 3 & 2 \\
\hline $6-12$ mj. & 1 & 10 & 10 & 3 & - & - & - \\
\hline $1-2$ god. & 10 & 2 & 4 & 1 & 2 & - & - \\
\hline $2-3$ god. & 2 & - & - & - & - & - & - \\
\hline $\begin{array}{c}\text { Ukupno } \\
\text { osuđenih } \\
\text { počinitelja }\end{array}$ & 59 & $\begin{array}{c}73 \\
(14 \text { žena) }\end{array}$ & $\begin{array}{c}82 \\
(11 \text { žena) }\end{array}$ & $\begin{array}{c}51 \\
(7 \text { žena) }\end{array}$ & $\begin{array}{c}24 \\
(6 \text { žena) }\end{array}$ & $\begin{array}{c}29 \\
(3 \text { žene) }\end{array}$ & $\begin{array}{c}31 \\
(3 \text { žene) }\end{array}$ \\
\hline
\end{tabular}

\footnotetext{
${ }^{100}$ Tablicu su izradili autori prema podatcima DZS-a.

${ }_{101}$ Nije postojao taj oblik kod kaznenog djela utaje poreza i drugih davanja u čl. 286. KZ-a iz 1997.

${ }^{102}$ Tablicu su izradili autori prema podatcima DZS-a.
} 
Prema podatcima Državnog zavoda za statistiku od 2010. do 2016. godine ${ }^{103}$ od ukupno 349 osuđujućih presuda za utaju poreza u 296 slučajeva izrečena je uvjetna osuda, što iznosi $85 \%$, a to je postotak koji korespondira sa zastupljenošću te modifikacije kazne u stopi ukupna kriminala. ${ }^{104}$ Te podatke potvrđuje i praksa Općinskoga kaznenog suda u Zagrebu koji je u svim dostupnim presudama obrađenima u ovom radu izricao uvjetnu osudu. Kazna zatvora relativno je slabo zastupljena za ta kaznena djela pa sudjeluje u izrečenim sankcijama sa $6 \%$ (2010. god.) do $22 \%$ (2016. god.).

\subsection{Odnos s drugim kaznenim djelima}

Potrebno je, prije svega, istaknuti da je kazneno djelo utaje poreza ili carine posebni oblik (lex specialis) kaznenog djela prijevare jer se prvim modalitetom (činjenjem), tj. davanjem netočnih ili nepotpunih podataka, odnosno lažnim prikazivanjem ili prikrivanjem činjenica nekoga (osobu koja radi u poreznoj upravi) dovodi u zabludu i time utječe na njega da odredi, tj. utvrdi porez manji od onoga koji bi trebalo, čime on nešto čini (utvrđuje porez) na štetu tuđe imovine (državnog proračuna). Drugim riječima, ispunjava se obilježje bića kaznenog djela prijevare (čl. 236. KZ-a). U tom kontekstu u takvim situacijama ne bi bio moguć realni stjecaj, nego prividni na temelju specijalnosti.

Činjenje kaznenog djela utaje poreza vrlo je često povezano i nalazi se u stjecaju s drugim kaznenim djelima poput kaznenog djela povrede obveze vođenja trgovačkih i poslovnih knjiga (čl. 248. KZ-a), kaznenog djela krivotvorenja isprave (čl. 278. KZ-a), kaznenog djela zlouporabe čeka i platne kartice (čl. 239. KZ-a) ili zlouporabe povjerenja u gospodarskom poslovanju (čl. 246. KZ-a). U praksi se nailazi na situacije u kojima se konstruira stjecaj između kaznenog djela utaje poreza i kaznenog djela povrede obveze vođenja trgovačkih i poslovnih knjiga (čl. 248. KZ-a). Dobro je da se u takvim situacijama konstruira stjecaj jer je za kazneno djelo povrede obveze vođenja trgovačkih i poslovnih knjiga (čl. 248. KZ-a) propisana kazna do tri godine zatvora, a za temeljeni oblik kaznenog djela utaje poreza ili carine (čl. 256., st. 1. KZ-a) propisana je kazna zatvora od šest mjeseci do pet godina; pa kada bi se uzelo da se osoba koja nije vodila knjige ne bi mogla kazniti za utaju poreza jer joj se nema na temelju čega obračunati porez koji je utajila, tada bi se ta osoba našla u privilegiranu položaju u odnosu na osobu koja je vodila knjige i utajila samo dio poreza. Stjecaj kaznenog djela utaje poreza (čl. 256. KZ-a) i povrede obveze vođenja trgovačkih

\footnotetext{
${ }_{103}$ DZS, Izvješće, br. 1605/2017, 142; DZS, Izvješće, br. 1576/2016, 146; DZS, Izvješće, br. 1528/2014, 126; DZS, Izvješće, br. 1504/2013, 116; DZS, Izvješće, br. 1478/2012, 126; DZS, Izvješće, br. 1451/2011, 152. Dostupno na http://www.dzs.hr/ (9.6.2018.).

${ }^{104}$ Derenčinović; Dragičević Prtenjača; Gracin, 2018, 129.
} 
i poslovnih knjiga (čl. 248. KZ-a) konstruirao je i Općinski kazneni sud u Zagrebu u predmetu K-1224/16 od 24. kolovoza 2016. jer je okrivljenik od 1. siječnja 2010. do 31. srpnja 2012. u Zagrebu propustio na plaće isplaćene u gotovini dvojici radnika zaposlenima u trgovačkom društvu obračunati, prijaviti i uplatiti porez na dohodak od nesamostalnog rada i prirez poreza na dohodak u ukupnu iznosu od 38.506,70 kuna. Osim toga, nije vodio poslovne knjige navedenoga trgovačkog društva, i to dnevnik, glavnu knjigu i pomoćne knjige te knjigu izlaznih i ulaznih računa, a na taj je način onemogućio uvid u nastale porezno bitne događaje, visinu i vrstu ostvarena prometa te iznose poreznih obveza za navedeno porezno razdoblje. Dakle, nije vodio trgovačke knjige ili poslovne knjige koje je po zakonu obvezan voditi. Okrivljenik je osuđen na jedinstvenu kaznu zatvora od 1 godine uz primjenu uvjetne osude tako da se izrečena kazna neće izvršiti ako u roku od 3 godine nakon pravomoćnosti presude ne počini novo kazneno djelo kao i da na ime imovinskopravnog zahtjeva isplati oštećenoj Republici Hrvatskoj iznos od 186.732,04 kuna u roku od 15 dana.

Tzv. friziranje knjiga, tj. unošenje pogrešnih ili neistinitih podatka, jedno je drugo kazneno djelo, krivotvorenje službene ili poslovne isprave (čl. 279. KZ-a). U praksi nisu rijetki ni slučajevi stjecaja kaznenog djela krivotvorenja službene ili poslovne isprave (čl. 279. KZ-a) s kaznenim djelom utaje poreza i carine bez obzira na to prepozna li ih sud ili ne. Krivotvorena isprava, tj. knjiga, upotrebljava se kao sredstvo za počinjenje kaznenog djela utaje poreza jer se predočava stanje koje ne odgovara stvarnom stanju i na temelju takva stanja razrezuje se porez. U tom je slučaju kaznenopravno riječ o idealnom stjecaju s obzirom na to da je počinitelj jednom radnjom počinio dva kaznena djela. Presudom Općinskoga kaznenog suda u Zagrebu, broj KO-214/15 od 1. prosinca 2015. godine, sud je presudio da je okrivljenik kriv što je od 1. travnja do 26. kolovoza 2008. godine kao direktor trgovačkog društva u nakani izbjegavanja plaćanja poreza s osnova koncesijske naknade za priređivanje igara na sreću u kasinima za travanj, svibanj i lipanj 2008. utvrđivao manju osnovicu za obračun te naknade, čime je počinio kazneno djelo iz čl. 286. Kaznenog zakona iz 1997. (dalje u tekstu: KZ iz 1997.). ${ }^{105}$ Sud je, međutim, propustio utvrditi da je takvo stanje okrivljenik prikazivao u poslovnim knjigama, čime je ostvario i kazneno djelo krivotvorenja službene isprave iz čl. 312. KZ-a iz 1997., pa je u tom kontekstu trebao konstruirati idealni stjecaj. Naravno, postoje i drugi slučajevi kada počinitelj usporedno s počinjenjem kaznenog djela utaje poreza čini i kaznena djela poput neisplate plaća, zlouporabe povjerenja u gospodarskom poslovanju ili zlouporabe čeka ili platne kartice. Potrebno je istaknuti da neplaćanje doprinosa u isplati plaća više nije kazneno djelo utaje poreza i carine kao što je bilo prije (čl. 286. KZ-a iz 1997., djelo je i nosilo naziv utaja poreza i drugih davanja), nego je danas kazneno djelo neisplate plaća (čl. 132. KZ-a).

\footnotetext{
${ }^{105}$ Kazneni zakon iz 1997., NN, br. 110/97, 27/98, 50/00, 129/00, 51/01, 111/03, 190/03, 105/04, 84/05, 71/06, 110/07, 152/08, 57/11.
} 
Može se zaključiti da utaja poreza u rijetkim slučajevima dolazi kao jedino kazneno djelo. U većini slučajeva utaja poreza bit će u stjecaju s drugim kaznenim djelima koja se upotrebljavaju da bi se ostvario krajnji cilj, a to je neplaćanje poreza državi i stjecanje protupravne imovinske koristi.

\section{KOMPARATIVNI PRIKAZ}

Usporedit će se pravni sustavi Njemačke i Švicarske radi davanja kratka prikaza i usporedbe zakonskih rješenja utaje poreza s hrvatskim kaznenopravnim sustavom jer se željelo vidjeti kako kazneno djelo utaje poreza reguliraju visokorazvijene europske zemlje, a i zbog toga što se hrvatsko kazneno pravo vrlo često vodi rješenjima tih dvaju kaznenopravnih sustava koja nerijetko služe kao uzori pri normiranju pojedinih zakonskih odredaba i rješenja.

\subsection{Analiza kaznenog djela utaje poreza u Njemačkoj}

Kazneno djelo utaje poreza u njemačkome kaznenom pravu regulirano je specijalnim sporednim zakonodavstvom, preciznije, člankom 370. Poreznog zakona (dalje u tekstu: NJPZ). Utaja poreza predikatno je kazneno djelo pranja novca, pa se u članku 261. njemačkoga Kaznenog zakona (Strafgesetzbuch, dalje u tekstu: StCB) ${ }^{106}$, kojim se regulira kazneno djelo pranja novca i skrivanja nezakonito stečenih financijskih povlastica ${ }^{107}$, navode nezakonite radnje kojima se može počiniti pranje novca, tj. predikatna kaznena djela. Među ostalim se navodi i članak 370. njemačkoga Poreznog zakona ${ }^{108} \mathrm{kojim}$ se uređuje utaja poreza (tax evasion). ${ }^{109}$ Nalazi se u osmom dijelu njemačkoga Poreznog zakona koji uređuje porezna kaznena djela te je sadržajno slično kaznenom djelu utaje poreza u hrvatskome kaznenom pravu iako ponešto drukčije. Tako će se kazniti kaznom zatvora, novčanom kaznom ili kaznom zatvora do 5 godina osoba koja dostavi poreznim ili drugim tijelima netočne ili nepotpune podatke koji su od bitna utjecaja na oporezivanje; propusti prijaviti poreznim tijelima

\footnotetext{
${ }^{106}$ Translation of the German Criminal Code provided by Prof. Dr. Michael Bohlander, Service provided by the Federal Ministry of Justice in cooperation with juris $\mathrm{CmbH}$ (2010), dostupno na https://ec.europa.eu/anti-trafficking/sites/antitrafficking/files/criminal_code_germany_en_1.pdf (26. 4. 2017.) i na https:// www.gesetze-im-internet.de/englisch_stgb/englisch_stgb.html\#p2147 (13.10.2017.).

107 Ibid., 119. Section 261 - Money laundering: hiding unlawfully obtained financial benefits.

${ }^{108}$ Fiscal Code of Cermany (2002) last amended by Article 5 of the Ordinance of 3 December 2015, Translation provided by the Language Service of the Federal Ministry of Finance, str. 233. Dostupno na https://www. gesetze-im-internet.de/englisch_ao/englisch_ao.html (8.6.2018.) i na https://www.bundesfinanzministerium.de/Content/EN/Standardartikel/Ministry/Laws/2015-01-01-fiscal-code.pdf?_blob=publicationFile\&v=3 (13.10.2017.).

${ }^{109}$ U nabrajanju se navode i prekršaji, među kojima i prekršaj iz čl. 370. NJPZ-a. Međutim, ta djela nisu prekršaji u smislu hrvatskoga pravnog poretka, nego su blaži oblici kaznenih djela za koje je propisana blaža zatvorska kazna ili novčana kazna te su kao takva djela definirana čl. 12. StCB-a.
} 
činjenice koje su od bitna utjecaja za oporezivanje kada je to bila obvezna; ili propusti koristiti se poreznim pečatima ili pečatnim uređajima kada je bila na to obvezna, a kao rezultat nastane nedovoljno plaćeni porez ili neopravdane porezne povlastice za nju ili neku drugu osobu. ${ }^{10}$ Pokušaj je utaje poreza prema njemačkome Poreznom zakonu kažnjiv."1' Kao i hrvatski Kazneni zakon predviđa i kvalificirani oblik utaje poreza koji se kažnjava kaznom od 6 mjeseci do 10 godina zatvora. ${ }^{112}$ Takva će se kazna primijeniti u posebno ozbiljnim slučajevima u kojima osoba namjerno utaji porez u većem iznosu ili iskoristi neopravdane porezne povlastice; utaji porez zloupotrebljavajući svoju vlast ili položaj javnog službenika ili europskoga javnog službenika; iskoristi pomoć navedenih službenika koji zloupotrebljavaju svoju vlast ili položaj; u više navrata utaji porez ili neopravdano iskoristi poreznu povlasticu koristeći se lažnim ili krivotvorenim dokumentima; te je član grupe koja je osnovana s ciljem činjenja navedenoga kaznenog djela (utaje poreza na dodanu vrijednost, trošarina ili iskorištavanjem trošarinskih povlastica). ${ }^{1{ }^{13}}$ Važno je spomenuti i članak 369 . NJPZ-a kojim je propisano da će porezna kaznena djela koja su predviđena navedenim zakonom biti predmet općih načela kaznenog prava osim ako nije drukčije predviđeno $u$ dijelovima poreznih zakona koji se tiču poreznih kaznenih djela. U tom se kontekstu može zaključiti da se na kazneno djelo utaje poreza načelno primjenjuju odredbe StCB-a, a samo u slučaju nekih drukčijih uređenja odredbe NJPZ-a kao lex specialis. NJPZ sadržava još jednu zanimljivu odredbu (čl. 371.) koja se odnosi na sva porezna kaznena djela za pojedine vrste poreza na koje se odnosi taj zakon. Tako se navodi da onaj koji potpuno ispravi netočne podatke koji su podneseni poreznim tijelima ili dopuni nepotpune podatke koji su podneseni poreznim tijelima ili poreznim tijelima dostavi prije izostavljene pojedinosti, neće potpadati pod kaznenu odgovornost za kazneno djelo utaje poreza. ${ }^{114}$ Takve informacije moraju se odnositi na sva porezna kaznena djela za koja nije nastupila zastara i za sva porezna kaznena djela pojedine vrste poreza u posljednjih 10 godina. ${ }^{15}$ Odredba se može usporediti s institutom djelotvornog kajanja ${ }^{16} \mathrm{u}$ hrvatskome kaznenom pravu. Međutim, Kazneni zakon u članku 256. koji uređuje kazneno djelo utaje poreza nije predvidio takvu odredbu koja bi predvidjela oslobođenje od kazne za počinitelja koji bi nakon dovršenja djela nastojao dostaviti cjelokupne podatke ili dopuniti nepotpune, prije dostavljene podatke. Takva se odredba u glavi kaznenih djela protiv gospodarstva jedino nalazi kod kaznenog djela pranja novca (čl. 265., st. 7. KZ-a). ${ }^{117}$

\footnotetext{
${ }^{110}$ Čl. 370., st. 1. NJPZ-a.

${ }^{111}$ Čl. 370., st. 2. N]PZ-a.

${ }^{112}$ Čl. 370., st. 3. NJPZ-a.

${ }^{113}$ Ibidem.

${ }_{114}$ Čl. 371. NJPZ-a.

115 Ibidem.

${ }^{116}$ Novoselec; Bojanić, 2013, 316.

${ }_{117}$ Čl. 265., st. 7. KZ-a: „Počinitelja iz stavka 1. do 5. ovoga članka koji dobrovoljno pridonese otkrivanju kaznenog djela kojim je ostvarena imovinska korist sud može osloboditi kazne."
} 


\subsection{Analiza kaznenog djela utaje poreza u Švicarskoj}

Utaja poreza u Švicarskoj slično kao i u Njemačkoj ne nalazi se u švicarskome Kaznenom zakonu (Schweizerisches Strafgesetzbuch, dalje u tekstu: SchStCB), nego u specijalnome sporednom zakonodavstvu, tj. Saveznom zakonu o izravnome federalnom oporezivanju (Bundesgesetz über die direkte Bundessteuer, dalje u tekstu: ŠSZIFO). ${ }^{118}$ Navedeni zakon ima nekoliko odredaba vezanih uz utaju poreza pa tako predviđa situacije potpune utaje poreza, pokušaja utaje poreza, poticanja, pomoći i supočiniteljstva u utaji poreza pa čak i situaciju uz utaju poreza kod bračnih drugova. Važno je napomenuti da švicarski Savezni zakon o izravnome federalnom oporezivanju za počinjenje kaznenog djela utaje poreza ne predviđa kaznu zatvora, nego samo novčanu kaznu. lako je za to djelo propisana samo novčana kazna, prema obilježjima koja su definirana u člancima švicarskoga Saveznog zakona o izravnome federalnom oporezivanju, a koji se nalaze pod glavom porezno kazneno pravo, proizlazi zaključak da je uistinu riječ o kaznenom djelu, a ne o prekršaju. Potpuna porezna utaja regulirana je člankom 175. ŠSZIFO-a, pa je propisano da će se novčanom kaznom kazniti svaka osoba koja kao porezni obveznik namjerno ili nehajno utječe na procjenu poreza tako da ona pogrešno ili protupravno izostane, odnosno da već pravomoćna procjena poreza bude nepotpuna. $U$ nastavku odredbe propisano je da isto vrijedi i za onoga tko kao izvorni porezni obveznik u svojstvu dužnika (npr. poslodavac koji plaća porez na dohodak svojim radnicima) ne odbije/plati poreznu olakšicu ili je ne odbije/plati potpuno te za onoga tko s namjerom ili iz nehaja nezakonito ostvari povrat poreza ili učini neopravdani nalog. Znači, počinitelj se kažnjava za namjerno i nehajno postupanje. Novčana kazna određena je u stavku 2. navedenog članka kao jedinstveni iznos utajenog poreza. Ona može biti smanjena do $1 / 3$ utajenog iznosa u slučaju manjeg stupnja krivnje, a u slučaju većeg stupnja krivnje novčana se kazna može utrostručiti. ${ }^{19}$ Zakonom je predviđena i situacija obustave postupka za poreznog obveznika koji prvi put sam prijavi utaju poreza ako su kumulativno ispunjena tri uvjeta: ako utaja poreza nije poznata nijednomu poreznom tijelu, ako navedeni porezni obveznik pomaže poreznoj upravi pri određivanju poreza te ako je porezni obveznik ozbiljan u naumu da plati dužni iznos poreza..$^{20}$ Ako dođe do novih samoprijavljivanja, novčana kazna smanjit će se na $1 / 5$ utajenog poreza uz ispunjenje prethodno navedenih uvjeta (čl. 175., st. 4. ŠSZIFO-a). Ta odredba slična je odredbi u njemačkom pravu i može se usporediti i s institutom djelotvornog kajanja u hrvatskome kaznenom pravu. Pokušaj je također kažnjiv i za njega je propisana kazna u iznosu od dvije trećine novčane kazne koja bi bila naplaćena u slučaju namjerne

\footnotetext{
${ }_{118}$ Bundesgesetz über die direkte Bundessteuer (DBC) vom 14. Dezember 1990 (Stand am 1. Januar 2017), dostupno na https://www.admin.ch/opc/de/classified-compilation/19900329/index.html (13.10.2017.).

119 Čl. 175., st. 2. ŠSZIFO-a.

${ }^{120}$ Čl. 175., st. 3. ŠSZIFO-a.
} 
i potpune utaje poreza. ${ }^{121}$ Člankom 177. ŠSZIFO-a propisane su kazne za poticanje, pomaganje i supočiniteljstvo u utaji poreza, a kazne se kreću od 10.000,00 franaka do 50.000,00 franaka u težim slučajevima. Ako se ispune pretpostavke iz članka 175., st. 3. ŠSZIFO-a pod a) i b) ${ }^{122}$, postupak će se obustaviti. Zanimljivost je toga Saveznog zakona i činjenica da je u članku 180. navedenog zakona definirana utaja poreza bračnih drugova tako da porezni obveznik koji se zakonito razveo od svoga bračnog druga odgovara samo za utaju poreza na temelju vlastitih poreznih faktora.

Švicarsko kazneno (porezno) zakonodavstvo razlikuje se od hrvatskog jer utaju poreza uređuje u svojemu poreznom pravu poreznim zakonom, ali i u tome što su za ta djela propisane isključivo novčane kazne. Izricanje novčane kazne nije isključeno ni u hrvatskome kaznenom pravu jer bi se za kazneno djelo utaje poreza ili carine moglo uz glavnu kaznu izreći i sporednu novčanu kaznu (u skladu s člankom 40., stavkom 5. $\mathrm{KZ}-a)^{123}$ iako takva praksa nije zamijećena $u$ analiziranim presudama. Zanimljiva je i razlika glede odredaba o sudioništvu (u užem i širem smislu) koje se u Švicarskoj nalaze u Saveznom zakonu o izravnome federalnom oporezivanju, dok se takve odredbe u hrvatskome kaznenom pravu nalaze u općim odredbama Kaznenog zakona i primjenjuju se na sva kaznena djela (propisana u glavnom ili sporednom zakonodavstvu).

\section{4. „POREZNE OAZE“-RA] ZA UTAJU POREZA ILI ZA LECALNE AKTIVNOSTI}

Činjenica je da gotovo sve države svijeta ponajprije žive od poreza i iz tog se rakursa može reći da sve države žele spriječiti odljev novca u strane zemlje, osobito u zemlje s niskim poreznim opterećenjima, tj. stopama, tzv. „poreznim oazama“ ili poreznim utočištima. ${ }^{124} \mathrm{U}$ tom su kontekstu upravo offshore-centri, odnosno porezne oaze, „živući" problem modernog svijeta pa se postavlja pitanje kakva je njihova povezanost s kaznenim djelom utaje poreza i čini li se predmetno kazneno djelo korištenjem takvim oazama. ${ }^{125}$ Krajem 20. stoljeća popularnost poreznih oaza iznimno je porasla te su ubrzo postale financijska središta. ${ }^{126}$ Danas svijet poreznih oaza i offshore-društava dovodi do slabljenja ekonomskih sustava država zbog svojih tajnih propisa i

\footnotetext{
${ }^{121}$ Čl. 176. ŠsZIFO-a.

${ }^{122}$ Da osoba sama prizna svoje radnje koje porezna tijela nisu otkrila i daje potporu poreznoj upravi na određivanju poreza.

${ }^{123}$ Tom normom predviđena je mogućnost izricanja novčane kazne (kao sporedne) za kaznena djela počinjena iz koristoljublja, a što bi utaja poreza zasigurno bila jer je stjecanje (protupravne) imovinske koristi motiv počinjenja djela.

${ }^{124}$ Vidi više u izvoru Juriša; Dražić Lutilsky, 2012, 69-73.

${ }^{125}$ Za više o poreznim oazama i koji je to problem s poreznog aspekta drugim državama, primjerice Sjedinjenim Američkim Državama, vidi Herman, 2014, dostupno na http://eds.a.ebscohost.com/eds/ ebookviewer/ebook/bmxlYmtfXzc1NTg3MVgfQU41?sid=5eeofa61-ccc5-463c-b862-1e6a371270a2@sessionmgr4009\&vid=3\&format=EB\&rid=1 (17.10.2017.).

${ }^{126}$ Sertić, 2012, 43.
} 
netransparentnosti koji privlače sve više stranih investitora u takve zemlje. ${ }^{127}$ Porezne oaze nazivaju se još i poreznim utočištima ili rajevima (tax havens), dok se tvrtke koje se registriraju u toj zemlji zovu offshore-društva. ${ }^{128,129}$ lako nema točne definicije poreznih oaza ${ }^{130}$, Organizacija za ekonomsku suradnju i razvoj (dalje u tekstu: OECD) u svom je izvješću 1988. godine dala četiri obilježja po kojima se može prepoznati porezna oaza, tj. utočište, a to su: a) područje bez niskoga poreznog opterećenja ili s njim, b) nedostatak učinkovite razmjene obavijesti, c) nedostatak transparentnosti i d) izostanak stvarne aktivnosti. ${ }^{131}$ Dakle, porezna oaza svaka je zemlja koja ispunjava navedena obilježja te u kojoj je omogućeno da strana osoba (fizička i pravna) osnuje offshore-društvo preko kojeg će umanjiti svoje porezne obveze. Zbog svojih je obilježja porezna oaza mjesto gdje ne samo strani investitori izbjegavaju porez nego vrlo vjerojatno i mjesto u kojem se "pere" novac ostvaren različitim kriminalnim aktivnostima. ${ }^{132}$

\subsection{Međunarodni standardi u borbi protiv poreznih oaza}

OECD je izradio liste država koje su prema navedenim obilježjima bile prepoznate kao porezne oaze. $U$ tom se kontekstu može reći da je borba protiv poreznih oaza i njihovo prepoznavanje kao „poreznog“ problema počela još davne 1970. godine kada je OECD napravio skicu Ugovora o razmjeni informacija za porezne svrhe. Međutim, prava borba službeno je počela 1996. godine kada su se u Lyonu susreli predstavnici zemalja $\mathrm{G} 7$ i tražili od OECD-a razvoj mjera za suzbijanje negativnih posljedica poreznih oaza. ${ }^{133}$ Dvije je godine poslije OECD izradio prvo izvješće o „štetnim“ poreznim sustavima u kojem se dao primarni osvrt na obilježja za prepoznavanje poreznih utočišta. Nastavak s daljnjom borbom protiv poreznih oaza uslijedio je 2000. godine kada je OECD u svom izvješću izradio "crnu listu“ od 35 država koje su se smatrale poreznim oazama u tom trenutku. $U$ tom izvješću nije navedeno šest država koje su sklopile različite ugovore kojima se obvezuju poduzeti specifične reforme da ne bi dospjele na listu poreznih oaza, a to su: Cipar, Kajmanski otoci, Malta, Mauricijus, San Marino i Bermuda. ${ }^{134}$ Nakon sastavljanja popisa OECD je kao glavnu preporuku državama članicama predložio izrađivanje pravnog okvira kojim bi se mogle implementirati predviđene obrambene mjere (nedopuštanje oslobođenja, izuzeća ili

\footnotetext{
127 Ibidem.

${ }_{128} \mathrm{Ibidem}$.

129 Offshore-trgovački poslovi sklopljeni u inozemstvu (izraz znači i: izvan obale, udaljeno od granice); Klaić, 2004, 964.

${ }^{130}$ Sertić, 2012, 42

${ }_{131}$ Organisation for Economic Cooperation and Development; Harmful Tax Competition: An Emerging Clobal Issue (1998), 23. Dostupno na https://www.oecd.org/tax/transparency/44430243.pdf (26.4.2017.).

132 Sertić, 2012, 43.

${ }^{133}$ Juriša; Dražić Lutilsky, 2012, 69.

${ }^{134}$ Sullivan, 2007, 327.
} 
drugih odbitaka povezanih uz transakcije s takvim zemljama ili korištenje njihovim režimima, zahtijevanje sveobuhvatnih informacija povezanih uz transakcije koje uključuju porezne oaze, uvođenje transakcijskih pristojbi na određene transakcije koje uključuju porezne oaze itd.) s ciljem sprječavanja takvih praksi u budućnosti. ${ }^{35}$ Tijekom vremena sve je više zemalja pristajalo na suradnju s OECD-om te je tako na izvornoj „crnoj listi“ ostajalo sve manje država. Suradnja se odnosila na obvezivanje o transparentnosti i razmjeni informacija. ${ }^{136}$ Tako su već 2002. godine na listi poreznih oaza ostale samo Andora, Lihtenštajn, Liberija, Monako, Maršalovi Otoci, Nauru i Vanatu, dok je 2004. ostalo samo 5 zemalja s obzirom na to da su se Nauru i Vanatu obvezale na transparentnost i razmjenu informacija. ${ }^{137} \mathrm{~S}$ ciljem prepoznavanja i suzbijanja „cvjetanja“ poreznih oaza OECD uveo je standard, tzv. „međunarodni porezni standard", koji je predstavio tijekom 2004. godine, a kojim se željelo obvezati porezne oaze na razmjenu informacija o svim poreznim pitanjima bez obzira na propise koji se odnose na banke i njihove klijente u poreznim oazama. ${ }^{138} \mathrm{~S}$ obzirom na činjenicu da je jedno od glavnih obilježja poreznih oaza tajnost i čuvanje podataka, donošenje tog standarda znatan je iskorak u borbi protiv poreznih oaza. Danas je lista nekooperativnih država svedena na nulu te ne postoji nijedna država koja nije prihvatila taj standard. lako je danas svaka porezna oaza formalno prihvatila navedeni standard, njegova primjena ostaje upitna. Standard funkcionira preko TIEA-e (Tax Information Exchange Agreements) odnosno Ugovora o međusobnoj razmjeni informacija vezanih uz porezna pitanja. ${ }^{139}$ Problemi nastaju u primjeni navedenih ugovora čiji efekti nisu onakvi kakvima su se očekivali. „Trenutačno je trideset zemalja potpisalo takve ugovore s trideset i tri offshore-zemlje."140,141 Isto tako neke porezne oaze, neovisno o veliku broju kompanija na njihovu teritoriju, ne vode podatke o direktorima ni o dioničarima takvih društava (npr. Britanski Djevičanski Otoci). ${ }^{142} \mathrm{~S}$ obzirom na poteškoće provođenja navedenih ugovora u praksi porezne oaze i dalje pružaju svoje usluge. ${ }^{143} \mathrm{U}$ tom kontekstu u Hrvatskoj ministar financija donosi popis država koje se smatraju poreznim utočištima i trenutačno ih je na popisu 50-ak. ${ }^{144}$

\footnotetext{
135 Ibid., 328.

${ }^{136}$ Craig, 2008, 68, dostupno na https://ssrn.com/abstract=1266329 (15.10.2017.).

${ }^{137}$ Juriša; Dražić Lutilsky, 2012, 70.

${ }^{138}$ Ibidem.

139 Juriša; Dražić Lutilsky, 2012, 71.

140 Ibidem.

${ }^{141}$ Hanlon; Maydew; Thornock, 2015, 263.

142 Ibidem.

${ }^{143}$ Popis država koje se smatraju poreznim oazama, tj. utočištima, dostupan je na http://www.racunovodja.hr/33/popis-dr-ava-na-koje-se-odnosi-odredba-l-31-st-10-zakona-o-porezu-na-dobit-vezano-za-porez-po-odbitku-uniqueidRCViWTptZH]3hZAWP4cu4sd-z67Fk2JV/ (16.10.2017.).

${ }^{144}$ Za više vidi na http://www.racunovodja.hr/33/popis-dr-ava-na-koje-se-odnosi-odredba-l-31-st-10zakona-o-porezu-na-dobit-vezano-za-porez-po-odbitku-uniqueidRCViWTptZH]3hZAWP4cu4sdz67Fk2JV/ (16.10.2017.).
} 
Treba napomenuti da i Europska unija (dalje u tekstu: EU) vodi borbu protiv poreznih oaza koja je ipak slabija od OECD-ove. EU je donio Direktivu 2003/48/EZ od 3. lipnja 2003. o oporezivanju dohotka od štednje isplaćena u obliku kamata koja se odnosi i na tri britanska krunska područja (Guernsey, otok Man i Jersey) i devet ovisnih ili pridruženih područja Kraljevine Nizozemske ili Ujedinjenog Kraljevstva (Aruba, Curacao, Sint Maarten, karipski dio Nizozemske, Anquilla, Britanski Djevičanski Otoci, Kajmanski otoci, Montserrat, otoci Turks i Caicos) te na države nečlanice s kojima je EU potpisao sporazume. ${ }^{145}$ Primjećuje se da se Direktiva odnosi osim na države članice EU-a i na zemlje s privlačnim poreznim sustavima kojih ima 60-ak. Direktiva obvezuje države članice EU-a da otkriju informacije poreznim vlastima drugih država članica EU-a. lako se Direktiva odnosi i na navedene nečlanice EU-a, neće biti previše od koristi ako porezna oaza nudi bankovnu tajnost jer naposljetku pojedinac neće biti oporezivan. Iz svega navedenog slijedi paradoksalna situacija u kojoj se zemlje s "privlačnim" poreznim sustavima formalno obvezuju na ugovore o razmjeni informacija vezanih za porezna pitanja te se zbog toga ne nalaze na "crnim listama“ štetnih poreznih sustava niti se službeno nazivaju poreznim oazama, a ipak i dalje pružaju svoje usluge uz anonimnost i niska ili nikakva porezna opterećenja. ${ }^{146}$

\subsection{Porezne oaze i kazneno djelo utaje poreza}

lako postoje formalni instrumenti kojima se zaista pokušava spriječiti odljev poreznih prihoda u porezne oaze, u stvarnosti se javljaju problemi. Unatoč potpisivanju ugovora o razmjeni informacija i prihvaćanju međunarodnih standarda, tzv. porezne oaze i dalje nude svoje usluge niskog ili nikakvog poreznog opterećenja uz zajamčenu anonimnost, dok zauzvrat traže samo naknade za osnivanje i održavanje. Vrlo je jednostavno danas osnovati offshore-društvo u jednoj od poreznih oaza. $\mathrm{Na}$ internetu je moguće pronaći sve potrebne podatke o osnivanju u nekoliko koraka i poslovanju offshore-društva kao i savjete poreznih stručnjaka u vezi s prednosti poslovanja preko-offshore društava (smanjenje poreznih obveza, tajnost podataka, upravljanje rizikom itd.). ${ }^{147}$ Naknade za osnivanje i održavanje offshore-društva razlikuju se od zemlje do zemlje ovisno o njezinim propisima. Važno je napomenuti da

\footnotetext{
145 Švicarska Federacija, Republika San Marino, Kneževina Andora, Kneževina Lihtenštajn i Kneževina Monako - EU Direktiva o kamatama na štednju (Direktiva 2003/48/EZ), dostupna na http://www. porezna-uprava.hr/Dostava_podataka_o_isplacenim_kamatama_na_stednju/Documents/DIREKTIVA\%200\%20KAMATAMA\%20NA\%20\%C5\%AOTEDNJU-informativno.pdf (13.10.2017.).

${ }^{146}$ Također je donesena Direktiva Vijeća 2011/16/EU od 15. veljače 2011. o administrativnoj suradnji u području oporezivanja i stavljanju izvan snage Direktive 77/799/EEZ (dalje u tekstu: Direktiva 2011) koja se „primjenjuje na sve poreze bilo koje vrste koje ubire država članica, teritorijalna ili upravna jedinica države članice, uključujući lokalna tijela ili se ubiru u njihovo ime", a radi razmjene podataka utvrđivanjem porezne osnovice u pojedinoj državi. Čl. 2., st. 1. Direktive 2011.

${ }_{147}$ Primjer takve internetske stranice: http://www.off-shore.net/hrvatski/
} 
samo osnivanje offshore-društva u nekoj od poreznih oaza nije kazneno djelo. Najčešći je oblik offshore-društva trgovačko društvo s ograničenom odgovornošću (na engl. LLC - Limited Liability Company) koje za svoje obveze odgovara cjelokupnom svojom imovinom, dok članovi samog društva načelno ne odgovaraju za obveze društva. No, ipak treba istaknuti članak 30. OPZ-a koji po uzoru na Zakon o trgovačkim društva (dalje u tekstu: ZTD) ${ }^{148}$ određuje odgovornost članova društva ${ }^{149}$ koji inače ne odgovaraju za obveze društva, i to zbog zloupotrebe prava, tj. korištenja društva radi ostvarivanja zakonom zabranjenoga cilja..$^{150}$ Zabranjeni bi cilj u svakom slučaju bila utaja poreza, pa ako je poslovanje smišljeno s namjerom utaje poreza, odgovorna osoba odgovarala bi svojom imovinom za nastale obveze društva, a ujedno bi činila i kazneno djelo iz čl. 256. KZ-a (ako su ispunjena sva njegova obilježja). U Republici Hrvatskoj ne postoji jedan sveobuhvatni zakon koji bi uređivao osnivanje i poslovanje offshore-društava, nego u pojedinim poreznim propisima postoje odredbe kojima se neizravno ili izravno referira na njih. S obzirom na to da će najčešće biti riječ o trgovačkim društvima i o njihovoj dobiti, posebna će se pozornost obratiti na odredbe ZPD-a (Zakona o porezu na dobit) koji u jednoj svojoj odredbi (čl. 31., st. 10.) izrijekom spominje porezna utočišta. ZPD u članku 31. (utvrđivanje i plaćanje poreza po odbitku) sadržava odredbe koje se odnose na nerezidente, tj. na strance ${ }^{151}$ koji

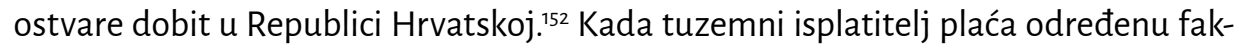
turu, tj. račun za neku uslugu propisanu čl. 31., st. 4. ZPD-a, u inozemstvo mora platiti tzv. porez po odbitku, koji prema čl. 31., st. 7. ZPD-a iznosi $15 \%$, tj. $12 \%$ za dividendu i udio u dobiti. Međutim, kada se takvo plaćanje usluga i onih koje nisu navedene u ZPD-u radi u nekom od poreznih utočišta, tada ta stopa poreza iznosi $20 \%$ \% je ustvari jedna od "obrambenih mjera" hrvatskoga poreznog sustava prema poslovanju s offshore-društvima. Dakle, ako se isplaćivanjem dobiti nerezidentu koji ima stvarno sjedište ili mjesto poslovanja u poreznoj oazi ne plati porez po odbitku s namjerom da se utaji porez te je uz to iznos utajenog poreza veći od 20.000,00 kuna, bit će riječ o kaznenom djelu utaje poreza. Primjerice, društvo u Republici Hrvatskoj potpuno legitimno osnuje offshore-društvo u nekoj od poreznih oaza te želeći utajiti porez na dobit od države, sklapa prividni pravni posao sa svojim offshore-društvom

\footnotetext{
${ }_{148}$ Zakon o trgovačkim društvima, NN, br. 111/93, 34/99, 121/99, 52/00, 118/03, 107/07, 146/08, 137/09, $125 / 11,152 / 11,111 / 12,68 / 13,110 / 15$.

${ }_{149}$ Čl. 30., st. 2. OPZ-a.

${ }_{150}$ Čl. 30., st. 3. OPZ-a.

151 Članak 3. ZPD-a: „(1) Rezidenti su u smislu članka 2., stavka 1. ovoga Zakona pravne i fizičke osobe čije je sjedište upisano u sudski ili drugi registar ili upisnik u Republici Hrvatskoj ili kojima se mjesto stvarne uprave i nadzor poslovanja nalazi u Republici Hrvatskoj. Rezidenti su i poduzetnici fizičke osobe s prebivalištem ili uobičajenim boravištem u Republici Hrvatskoj čija je djelatnost upisana u registar ili upisnik. (2) Nerezident je osoba koja ne ispunjava jedan od uvjeta iz stavka 1. ovoga članka." 152 Čl. 31., st. 1. ZPD-a.

153 Čl. 31., st. 10. ZPD-a.
} 
koje „nudi“ usluge u Republici Hrvatskoj. Isplatom dobiti za taj prividni pravni posao društvo iz Republike Hrvatske (rezident) kao isplatitelj ne plati porez po odbitku, a time i porez na dobit, i tada zalazi u područje kaznenopravne odgovornosti iz članka 256. KZ-a. Sklapanje prividnog posla upućuje i na vrlo vjerojatno postojanje i nekih drugih kaznenih djela, ponajprije krivotvorenja službene ili poslovne isprave iz članka 279. KZ-a. S obzirom na to da društvo nije platilo porez po odbitku odnosno porez na dobit, cjelokupna dobit ide offshore-društvu koje u poreznoj oazi ne mora platiti porez na prihode iz inozemstva ili ga mora platiti u neznatnu iznosu. Prikazanim postupkom društvo koje je osnovalo offshore-društvo u poreznoj oazi ima pristup cjelokupnoj dobiti koja nije umanjena za utajeni porez. Pri sklapanju prividnih pravnih poslova uspostavlja se odgovornost odgovorne osobe trgovačkog društva koje je osnovalo offshore-društvo s kojim je zaključilo prividni pravni posao, i to kao poreznog jamca ${ }^{154}$, a što onda upućuje i na moguće izvođenje i utvrđivanje kaznene odgovornosti takve osobe prema Zakonu o odgovornosti pravnih osoba za kaznena djela (dalje u tekstu: ZOPOKD). ${ }^{155}$

\section{ZAKLJUČAK}

Iz raznih napisa u medijima proizlazi da je kazneno djelo utaje poreza vrlo zastupljeno u Hrvatskoj, dok podatci DZS-a i praksa hrvatskih sudova pokazuju sasvim drukčije činjenično stanje, čak dijametralno suprotno. Zastupljenost je te vrste kriminala među gospodarskim kaznenim djelima oko $8 \%$, a u ukupnu kriminalu (za 2016. godinu) zastupljenost iznosi manje od $1 \%(0,4 \%$ ), što je uistinu malen postotak i nije statistički bitan rezultat. Za to se kazneno djelo najčešće izriče uvjetna osuda kao modifikacija kazne zatvora i to čak u $85 \%$ slučajeva. Sasvim je drugo pitanje otkrivanja, prepoznavanja, tj. pravilnog pravnog kvalificiranja i procesuiranja tih kaznenih djela, odnosno tamne brojke te vrste kriminala. Clavnu ulogu u otkrivanju kaznenih djela utaje poreza trebala bi imati porezna tijela te o tome obavještavati nadležna pravosudna tijela, a što im je i propisana obveza prema odredbama Općega poreznog zakona (čl. 8., st. 6. i čl. 123. OPZ-a). Njemačka i Švicarska vjerojatno iz tog ili slična razloga imaju propisana porezna kaznena djela u poreznom zakonodavstvu, pa porezna tijela odmah znaju o kojim će poreznim kaznenim djelima biti riječ ako porezni obveznici i druge osobe koje bi bile dužne platiti porez to ne učine, a time su svjesni i svoje važne uloge u otkrivanju i prijavljivanju tih kaznenih djela. Međutim, vrlo je problematično postojeće rješenje predviđeno čl. 11., st. 2. OPZ-a kojim se na neki način daje uputa poreznim tijelima da razrežu porez na svaku korist (prihod), pa i onu stečenu nezakonito, tj. protupravno. Ponavlja se da se takvo rješenje smatra

${ }^{154}$ Čl. 31. toč. 2., čl. 32. i 33. OPZ-a.

155 Čl. 3. i 4. Zakona o odgovornosti pravnih osoba za kaznena djela, NN, br. 151/03, 110/07, 45/11, 143/12. 
nedopustivim jer takva osoba snosi dvostruki imovinski teret. Kao što je navedeno u tekstu, eventualno bi trebala postojati mogućnost razrezivanja poreza na nezakonito stečenu imovinu kada se ona ne oduzme $u$ kaznenom postupku.

Nadalje, u vezi s postavljenim hipotezama može se zaključiti da je razgraničenje utaje poreza kao prekršaja od utaje poreza kao kaznenog djela relativno dobro učinjeno Kaznenim zakonom i člankom 256. KZ-a te tumačenjem tog članka u praksi, ponajprije od VSRH-a (Kž 818/2012 i Kž 882/12). U tom kontekstu nije svako neplaćanje poreza višeg od $20.000,00 \mathrm{kn}$ kazneno djelo. Svako je neplaćanje poreza porezna evazija i češće je prekršaj nego kazneno djelo, ovisno o visini iznosa i činjenicama slučaja. Tako ako je osoba koja je dužna platiti porez dala netočne ili nepotpune podatke, a iznos poreza ne prelazi 20.000,00 kuna, bit će riječ o prekršaju. S druge strane, ako je osoba koja je dužna platiti porez dala netočne ili nepotpune podatke, a iznos neplaćenog poreza veći je od 20.000,00 kuna, bit će riječ o kaznenom djelu. Međutim, ako je iznos neplaćenog poreza veći od 20.000,00 kuna, a nije bila riječ o utaji, tj. o davanju netočnih ili nepotpunih podataka, nego jednostavno o nemogućnosti plaćanja (nedovoljnim sredstvima na računu i sl.), neće biti riječ o kaznenom djelu utaje poreza, nego o prekršaju, što je potvrdio i Vrhovni sud Republike Hrvatske u svoje dvije odluke (Kž 818/2012 i Kž 882/12). U skladu s navedenim može se zaključiti da je prva hipoteza, $\mathrm{H} 1$ : svaka porezna evazija veća od 20.000,00 kuna kazneno je djelo utaje poreza, provjerena i opovrgnuta.

Vezano za drugu hipotezu, H2: poslovanje preko poreznih utočišta nezakonito je i označuje kazneno djelo utaje poreza, može se zaključiti, ako se poštuju svi zakonski propisi, primjerice Zakon o porezu na dobit, i plaća se porez po odbitku i eventualno drugi propisani porezi, neće biti riječ ni o jednom obliku porezne evazije, pa se može reći da društva koja imaju sjedište u Hrvatskoj (tuzemna društva, pravne i druge fizičke osobe) i koja posluju s offshore-društvima zakonito posluju. Drukčija je situacija, ako ta društva (i fizičke osobe) ne plate poreze propisane hrvatskim propisima, tada ovisno o namjeri, tj. činjenicama i okolnostima postupanja (davanje netočnih podataka ili nedavanje podatka ili davanje nepotpunih podataka) te o iznosu utajenog poreza može biti riječ o prekršaju ili kaznenom djelu, a kako je to objašnjeno uz prvu hipotezu. U tom se kontekstu može reći da je i druga hipoteza provjerena i opovrgnuta.

\section{LITERATURA}

1. ACCA, Paper F6, Taxation (UK) FA 2013; https://books.google.hr/books?id=L-

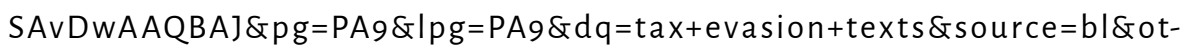
$s=z x Z o w W V f Z o \& s i g=H F C o F Q A z M O i Q g t 72 W n P-Z 1 j u d O w \& h l=h r \& s a=X \& v e d=0 a h U-$ KEwi9886mnffWAhX]b1AKHTHWCHcQ6AEIQDAF\#v=onepage\&q=tax\%20evasion\%20 texts\&f=false (17.10.2017.). 
2. Bačić, F.; Šeparović, Z., (1992). Krivično pravo - posebni dio. Zagreb.

3. Bačić, F.; Pavlović, Š., (2001). Kazneno pravo - posebni dio. Zagreb.

4. Bojanić, I.; Cvitanović, L.; Derenčinović, D.; Grozdanić, V.; Kurtović, A.; Novoselec, P.; Turković, K., (2007). Posebni dio kaznenog prava. Zagreb.

5. Cindori, S.; Pilipović, O.; Kalčić, R., (2015). Porez na dodanu vrijednost u teoriji i praksi. Split.

6. Craig, M. B., (2008). Regulating tax competition in offshore financial centers; dostupno na https://ssrn.com/abstract=1266329 (17.10.2017.).

7. Derenčinović, D.; Getoš, A. M., (2008). Uvod u kriminologiju s osnovama kaznenog prava. Zagreb.

8. Derenčinović, D.; Dragičević Prtenjača, M.; Gracin, D., (2018). Alternative kazni oduzimanja slobode. U: Alternativne krivične sankcije (regionalna krivična zakonodavstva, iskustva u primeni i mere unapređenja), Beograd.

9. Garačić, A., (2013). Pravna shvaćanja o neodređenim vrijednostima koje su zakonsko obilježje kaznenog djela, stjecaj i produljeno kazneno djelo-primjena blažeg zakona, 1-32, dostupno na http://www.vsrh.hr/CustomPages/Static/HRV/Files/ACaracic_Pravna-shvacanja-o-neodredjenim_Opatija_2013.pdf (12.10.2017.).

10. Hanlon, M.; Maydew, E. L.; Thornock, J. R., (2015). Taking the Long Way Home: U. S. Tax Evasion and Offshore Investments in U. S. Equity and Debt Markets, The Journal of the American finance association, No. 1.

11. Harel, A., (2014). The Contribution of Carry Becker u Foundational Texts in Modern Criminal Law, ur. Dubber, Markus D., Oxford: Oxford University Press, dostupno na https://books.google.hr/books?id=y89LBAAAQBA]\&pg=PA313\&lpg=PA313\&dq=tax+evasion+texts\&source=b|\&ots=V-iF8CStFs\&sig=k7q2udtmswKIU1Y2eLHtrZUrtNQ\&hl=hr\&sa=X\&ved=oahUKEwi9886mnffWAhXJb1AKHTHWCHcQ6AEIRTA-

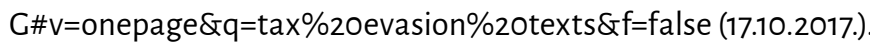

12. Herman, M., (2014). Offshore Tax Evasion: U. S. Efforts to Collect Unpaid Taxes and the Credit Suisse Case, New York: Nova Science Publishers, Inc., dostupno na http://eds.a.ebscohost.com/eds/ebookviewer/ebook/bmxlYmtfXzc1NTg3MV9fQU41?sid=5eeofa61-ccc5-463c-b862-1e6a371270a2@sessionmgr4009\&vid=3\&format=EB\&rid=1 (17.10.2017.).

13. Horvatić, Ž.; Derenčinović, D.; Cvitanovć, L. (2016). Kazneno pravo-opći dio 1- kazneno pravo i kazneni zakon. Zagreb.

14. Horvatić, Ž.; Derenčinović, D.; Cvitanovć, L. (2017). Kazneno pravo opći dio 2 - kazneno djelo i kaznenopravne sankcije. Zagreb.

15. Horvatić, Ž.; Šeparović, Z. i sur., (1999). Kazneno pravo - posebni dio. Zagreb.

16. Jančiev, Z.; Supić, J. (2016). Hrvatski porezni sustav. Institut za javne financije, Zagreb.

17. Jelčić, B.; Lončarić-Horvat, O.; Šimović, J., Arbutina, H., Mijatović, N. (2008). Financijsko pravo i financijska znanost. Narodne novine.

18. Juranić, I., (1965). Krivično djelo porezne utaje: (s osvrtom na praksu Okružnog suda Zagreb), magistarske radnje branjene na Pravnom fakultetu u Zagrebu, Zagreb. 
19. Juriša, J.; Dražić Lutilsky, I., (2012). Porezna evazija pomoću poreznih oaza - borba protiv poreznih oaza. Računovodstvo i financije 3, 69-73.

20. Klaić, B. (2004). Rječnik stranih riječi. Nakladni zavod Matice hrvatske. Zagreb.

21. Kurtović, Š. (2005). Opća povijest prava i države-stari i srednji vijek. Zagreb.

22. Križanec, ]. (2016). Porezna evazija. Institut pravo/finansije.

23. Matković, B., (2013). Prekršajna i kaznena odgovornost za neplaćanje poreza i carine. Računovodstvo, revizija i financije 12/13.

24. Mladineo, I. (2008). Otkrivanje utaja poreza i doprinosa - Jednaki pristup prema svim poreznim obveznicima. U: Korupcija - pojavni oblici i mjere za suzbijanje, ur. Jasminka Hercigonja i Marica Kuzmić. Inženjerski biro, 46-65.

25. Mršić, G., (2008). Kazneno djelo utaje poreza i drugih davanja - poseban osvrt na slučajeve iz prakse. Radno pravo: stručni časopis 3, 51-56.

26. Munivrana Vajda, M., (2011). Genocid u svjetlu općih institucija materijalnog kaznenog prava, doktorska disertacija, Zagreb.

27. Novoselec, P.; Bojanić I. (2013). Opći dio kaznenog prava. Zagreb.

28. Novoselec, P. (2016). Opći dio kaznenog prava. Osijek.

29. Novoselec, P.; Roksandić Vidlička, S., (2010). Cospodarska kaznena djela u novom Kaznenom zakonu. Hrvatski ljetopis za kazneno pravo i praksu 17: 2, 699-728.

30. Sertić, A., (2012). Porezne oaze: međunarodno izbjegavanje plaćanja poreza i porezna evazija. Porezni vjesnik 5.

31. Sokanović, L.; Šinković, Z.; Pajčić, M., (2012). Utaja poreza i drugih davanja u sportu. Zbornik radova Pravnog fakulteta u Splitu 49:4, 803-830.

32. Schönke, A.; Schröder, H. (1997). Strafgesetzbuch, Kommentar 25, Auflage, C. H. Beck, München.

33. Sullivan M. A., (2007). Lessons From the Last War on Tax Havens, Tax notes, dostupno na https://www.taxjustice.net/cms/upload/pdf/Tax_Notes_0707_Lessons_from_the_war_ on_tax_havens.pdf (17.10.2017.).

34. Šimović, J.; Rogić Lugarić, T.; Cindori, S., (2007). Utaja poreza u Republici Hrvatskoj. Hrvatski ljetopis za kazneno pravo i praksu 14: 2, 591-617.

35. Škulić, M., (2017). Krivično delo silovanja u Krivičnom pravu Srbije - aktuelne izmene, neka sporna pitanja i moguće buduće modifikacije. Crimen - revija za kriminologiju i krivično pravo 55: 2-3/2017.

36. Turković, K.; Novoselec, P.; Grozdanić, V.; Kurtović Mišić, A.; Derenčinović, D.; Bojanić, I.; Munivrana Vajda, M.; Mrčela, M.; Nola, S.; Roksandić Vidlička, S.; Tripalo, D.; Maršavelski, A. (2013). Komentar Kaznenog zakona. Narodne novine. Zagreb.

37. Zlatarić, B. (1958). Krivični zakonik u praktičnoj primjeni- posebni dio, Il svezak, Zagreb. 
1. Bundesgesetz über die direkte Bundessteuer (DBC) vom 14. Dezember 1990 (Stand am 1. )anuar 2017), dostupno na https://www.admin.ch/opc/de/classified-compilation/19900329/index.html (13.10.2017.).

2. Direktiva Vijeća 2011/16/EU od 15. veljače 2011. o administrativnoj suradnji u području oporezivanja i stavljanju izvan snage Direktive 77/799/EEZ.

3. EU Direktiva o kamatama na štednju (Direktiva 2003/48/EZ), dostupna na http://www.porezna-uprava.hr/Dostava_podataka_o_isplacenim_kamatama_na_stednju/Documents/ DIREKTIVA\%200\%20KAMATAMA\%20NA\%20\%C5\%AOTEDNJU-informativno.pdf (13. 10. 2017.).

4. Fiscal Code of Cermany (2002) last amended by Article 5 of the Ordinance of 3 December 2015, Translation provided by the Language Service of the Federal Ministry of Finance, dostupno na https://www.gesetze-im-internet.de/englisch_ao/englisch_ao.html (26. 4. 2017.) i na https://www.bundesfinanzministerium.de/Content/EN/Standardartikel/Ministry/ Laws/2015-01-01-fiscal-code.pdf?_blob=publicationFile\&v=3 (13.10.2017.).

5. Kazneni zakon iz 1997., NN, br. 110/97, 27/98, 50/00, 129/00, 51/01, 111/03, 190/03, 105/04, 84/05, 71/06, 110/07, 152/08, 57/11, 143/12.

6. Kazneni zakon, NN, br. 125/11, 144/12, 56/15, 61/15, 101/17.

7. Opći porezni zakon, NN, br. 115/16.

8. Prekršajni zakon, NN, br. 107/07, 39/13,157/13,110/15, 70/17.

9. Translation of the German Criminal Code provided by Prof. Dr. Michael Bohlander, Service provided by the Federal Ministry of Justice in cooperation with juris $\mathrm{CmbH}$ (2010), dostupno na https://ec.europa.eu/anti-trafficking/sites/antitrafficking/files/criminal_code_ germany_en_1.pdf (26.4.2017.) i na https://www.gesetze-im-internet.de/englisch_stgb/ englisch_stgb.html\#p2147 (13.10.2017.);

10. Zakon o kaznenom postupku, NN, br. 152/08, 76/09, 80/11, 91/12, 143/12, 56/13, 145/13, $152 / 14,70 / 17$

11. Zakon o odgovornosti pravnih osoba za kaznena djela, NN, br. 151/03, 110/07, 45/11, 143/12.

12. Zakon o porezu na dobit, NN, br. 177/04, 90/05, 57/06, 146/08, 80/10, 22/12, 148/13, 143/14, $50 / 16,115 / 16$.

13. Zakon o trgovačkim društvima, NN, br. 111/93, 34/99, 121/99, 52/00, 118/03, 107/07, 146/08, $137 / 09,125 / 11,152 / 11,111 / 12,68 / 13,110 / 15$.

1. Izvješće DZS-a, br. 1605/2017, Punoljetni počinitelji kaznenih djela, prijave, optužbe i osude u 2016., Zagreb, 2017.

2. Izvješće DZS-a, br. 1576/2016, Punoljetni počinitelji kaznenih djela, prijave, optužbe i osude u 2015., Zagreb, 2016.

3. Izvješće DZS-a, br. 1551/2015, Punoljetni počinitelji kaznenih djela, prijave, optužbe i osude u 2014., Zagreb, 2015.

4. Izvješće DZS-a, br. 1528/2014, Punoljetni počinitelji kaznenih djela, prijave, optužbe i osude u 2013., Zagreb, 2014 
5. Izvješće DZS-a, br. 1504/2013, Punoljetni počinitelji kaznenih djela, prijave, optužbe i osude u 2012., Zagreb, 2013.

6. Izvješće DZS-a, br. 1478/2012, Punoljetni počinitelji kaznenih djela, prijave, optužbe i osude u 2011., Zagreb, 2012.

7. Izvješće DZS-a, br. 1451/2011, Punoljetni počinitelji kaznenih djela, prijave, optužbe i osude u 2010., Zagreb, 2011.

8. Organisation for Economic Cooperation and Development; Harmful Tax Competition: An Emerging Clobal Issue (1998), dostupno na https://www.oecd.org/tax/transparency/44430243.pdf (26.4.2017.).

\section{Summary}

\section{TAX EVASION AS A CRIMINAL OFFENCE WITH SPECIAL REFERENCE TO TAX HAVENS}

The paper deals with the question of whether any unpaid tax can be considered to constitute tax evasion, and whether any tax evasion is a criminal offence. In that regard the authors investigate the problem of whether doing business via the so called tax havens is legal orillegal. If business via tax havens constitutes tax evasion, should this be considered a criminal offence? In this context two hypotheses have been set up: $\mathrm{H1}$ : Every tax evasion is a criminal offence; $\mathrm{H}_{2}$ : Business via tax havens is illegal and constitutes a criminal offence of tax evasion.

Key words: taxes, tax evasion, criminal offence of tax evasion, tax havens 